\title{
Improving Motivation to Learn English in Japan with a Self-Study Shadowing Application
}

\author{
Jennifer Louise Teeter
}

Institute for Liberal Arts and Sciences, Kyoto University, Yoshida-honmachi, Sakyo-ku, Kyoto 606-8501, Japan; teeter.jenniferlouise.5u@kyoto-u.ac.jp; Tel.: +1-224-217-9888

Academic Editors: Sonia Rocca and Bryan Smith

Received: 28 February 2017; Accepted: 29 August 2017; Published: 27 September 2017

\begin{abstract}
The scarcity of opportunities to communicate in English in Japan proves a challenge for learners, as significant improvements in English as a Foreign Language) (EFL) listening and speaking will not materialize without consistent practice and a motivation to study. Furthermore, analysis of standardized test scores shows that university students' scores tend to decrease after their first year of study (Sumida 2015; Mikada 2016). In order to overcome these difficulties, a team of teachers at a university in Japan introduced a mobile-assisted language learning (MALL) shadowing application where students can train their ears while also practicing speaking with shadowing, a technique recognized as effective for improving speaking and listening (Kadota 2014; Hamada 2016). This paper describes the introduction of this application in general education English classes. It then considers its impact on the motivation, attitudes towards communicating orally in English, and perception of English ability of 1001 first-year university students, the majority science and engineering majors, who used it over one semester. Preliminary results of a pre- and post-intervention Likert questionnaire indicate that through this system, linguistic self-confidence, interest in English, ideal L2 self, attitudes towards communicating in the L2, and perceptions of English ability were potentially enhanced.
\end{abstract}

Keywords: shadowing; second language motivation; attitudes; MALL; Japan; L2 listening; L2 speaking; English as a Foreign Language; English as a Second Language; anxiety; linguistic self-confidence

\section{Introduction}

The importance of acquiring oral English communication proficiency continues to grow in Japan. Japan-based multi-national corporations, such as Uniqlo and Rakuten have made English their official language [1] and researchers in the fields of science and engineering are experiencing more pressure to produce academic papers and present at conferences in English [2]. These societal changes have reverberated at the policy level, as the Ministry of Education, Culture, Sports, Science and Technology (MEXT) is working to improve students' English communication skills through significant curriculum changes. At present, foreign language education, which is essentially synonymous with "white middle class [American] English" [3], is compulsory in the fifth and sixth grades of elementary school and all of junior high. Starting from 2020, the new curriculum changes are making foreign language education classes mandatory from primary third grade, and 120 primary schools are currently serving as test schools for the new textbooks that will be used [4]. In addition, MEXT has mandated that all these classes at the junior and senior high school level be taught in English [5].

In turn, universities in Japan are increasingly responding to these same pressures to improve students' English communicative competence by increasing the number of English language and English-medium courses in their curricula [6]. However, with an overall lack of English language exposure outside of the classroom for most students, opportunity for study is often limited to one to a few 90-min sessions a week. Although there is a prevalence of classes titled "Oral 
Communication" in universities across the country, a variety of factors, including class size, lack of oral communication-focused activities, and other classroom issues, often prevent these classes from being true to their given names. In order for a person to retain new words and phrases, high quality, frequent and deliberate practice is necessary [7]. Additionally, studies of how proficiency test scores change after students enter university show that by the end of students' first year, scores on Test of English for International Communication (TOEIC) and Test of English as a Foreign LanguageInstitutional Testing Program (TOEFL-ITP) decline [8,9]. In addition, at the university where this study was conducted, surveys show that listening scores are relatively low compared to reading $[10,11]$.

Given the situation of English-language scarcity in Japan, motivation and attitudes towards English are factors that could also influence students' English learning success. Motivation has been defined as a "combination of effort plus desire to achieve the goal of learning the language plus favorable attitudes towards learning the language" [12] (p. 10). Ellis describes how motivation and attitudes impact the amount of exertion a student puts into language learning: "motivation involves the attitudes and affective states that influence the degree of effort that learners make to learn an L2" [13] (p. 75). The definition by Ajzen of an attitude is commonly used in second language acquisition literature, "an attitude is a disposition to respond favorably or unfavorably to the object, person, institution, or event" [14] (p. 3). In other words, if learners have positive attitudes towards the target language, their motivation to learn the language could be higher. Furthermore, because motivation and attitudes towards learning a target language are considered predictors of second language learning achievement, enhancing student motivation and attitudes towards English can have a positive impact on their second language learning. The lack of English study opportunity has impacts on every English learner, but motivation can give them the drive to effectively utilize listening and speaking opportunities that exist, and create opportunities as well. Assessing how and if learning techniques and teaching strategies employed in certain contexts influence student engagement is important to delivering effective language courses $[15,16]$.

To address the difficulties outlined above in learning to speak English, the use of mobile-assisted language learning (MALL) technology in English as a Second Language (ESL) and English as a Foreign Language (EFL) classrooms is gaining traction because of its ability to provide flexible access to language learning materials. Shadowing is one technique considered effective for improving listening and speaking [17], yet students often lack access to appropriate shadowing materials. Research also suggests that shadowing [18] and MALL technology [19] independently of each other can enhance learner motivation. Nonetheless, either a small number of participants or a lack of detailed analysis of motivational variables limits studies in both areas. Exploring the impacts on learners' motivation of combining shadowing with MALL technology may prove fruitful. Therefore, taking advantage of the high ownership rates of smart phones by university students, a team of researchers at a high-ranking university in Japan introduced a self-study shadowing application for smart phones, tablets, and computers ("shadowing intervention") for first-year university students mainly majoring in science and engineering (S\&E) $[11,20]$. The purpose of this shadowing intervention is to provide students with opportunities to practice speaking and listening without the restraints of time and space. Keeping in mind that learners' motivation is connected, even if indirectly, to language learning success, this study explores how the use of the shadowing application influences learners' motivation and gains in listening and speaking proficiency. Drawing upon previous studies based on motivation and attitudes towards L2 learning $[17,21]$, this article will address the following questions:

1. How do student perceptions of their English listening and speaking ability change due to the shadowing intervention?

2. How does students' motivational intensity related to studying listening and speaking change after shadowing for 12 weeks?

3. What are students' attitudes towards shadowing?

4. How does time spent shadowing correlate with self-evaluation of English listening and speaking ability? 
5. How does time spent shadowing correlate with changes in motivation?

This article first provides an overview of past studies on the use of MALL technology in education and shadowing for second language acquisition both in general and in the Japanese context. After outlining work in motivation studies, it then hypothesizes on how combining MALL with shadowing can potentially enhance students' motivation and proficiency. A description of the research design involving a Likert-based questionnaire follows. While analysis is primarily statistical in nature, this study by no means attempts to support the assumption that statistical analysis paints a complete picture of students' motivation and attitudes. Like Pigott, the author of this study concurs-statistics is not the "de rigueur means of investigation" [22] (p. 28); statistical studies like this may, however, provide some insight into students' perceptions. Finally, analysis of the results and suggestions for future research will follow.

\section{Literature Review}

\subsection{Mobile-Assisted Language Learning}

Research into mobile learning entails more than simply examining learning outcomes through teaching materials delivered via mobile devices, such as smart phones, tablets, mp3 players, and personal data assistants. Rather the definition has evolved and is now referred to as "the study of how the mobility of learners augmented by personal and public technology can contribute to the process of gaining new knowledge, skills and experience" [23] (p. 235). Examining how learners' interaction with mobile technology transcends the constraints of time and space to transform the learning process is key. Mobile-assisted language learning (MALL is a sub-branch of computer-assisted language learning (CALL) and mobile learning where the teaching of languages and/or language learning is enhanced or assisted through the use of mobile devices [24].

Educators have been debating the merits and demerits of using mobile technology in the classroom, especially given the growth in student ownership of mobile devices. Results from a 2015 Pew Research Center survey indicate that smart phone ownership in Japan for people aged 18-34 is 77\% [25] and high school student ownership is estimated to be as high as 93\% [26]. Rather than resist the growth of the so-called "digital native" population, framed as being highly familiar with information and communication technology, educators are beginning to embrace it [27]. It is important to note however, that assumptions about students' familiarity with technology can lead to poor pedagogical decisions. Overemphasizing access to technology can divert attention from examining whether the technology in question can make teaching and learning more effective [28].

While bearing this in mind, MALL applications are proving beneficial to learners in non-immersion settings by creating seamless learning opportunities for language learners [29]. Several studies have demonstrated the potential of MALL use to positively impact speaking and listening skills [30,31], increase learner recollection of target vocabulary, and enhance learner autonomy [32]. One small-scale study at a Japanese university found that daily vocabulary emails improved vocabulary retention in comparison with traditional methods. Students in the study reported that they prefer this use of MALL technology to paper-based materials [33]. More studies are needed, however, that specifically analyze how MALL can be utilized to enhance teaching, different aspects of learning, motivation, and attitudes.

\subsection{Shadowing}

In the field of second language acquisition (SLA), shadowing is a broad term referring to a technique where auditory material is repeated almost simultaneously either silently or out loud. Originally used in cognitive psychology to test selective attention [34], it has also been utilized by doctors for language therapy to help treat stuttering [35], and by interpreters for training purposes [36]. Murphey outlined three variations of shadowing: verbatim, focusing on certain words, and interactive with another speaker [37]. Hamada further delineated categories to include pre-shadowing/bottom-up 
shadowing where a script is read and studied prior to shadowing, and post-shadowing/top-down shadowing carried out without preliminary use of a script [38]. The study employed verbatim shadowing, either pre-shadowing or top-down shadowing.

Several studies of shadowing examined the positive impacts it can have on speaking proficiency. In Foote and McDonough's recent study in Canada, sixteen participants practiced shadowing short dialogues for eight weeks on iPods (Apple Inc., Cupertino, CA, USA), and then did an extemporaneous speaking task. Results based on twenty-two non-expert raters indicated that their comprehensibility, and fluency improved [39]. Rongna and Hayashi's, in their study involving students of Japanese as a foreign language, suggested that shadowing influenced speech rate and accuracy of pitch accent positively [40], with Yamane et al. (cited in Bovee and Stewart, [34]) citing improvements in student pitch range from 17.7 to $68.3 \%$ after studying English through shadowing [41]. Torikai, et al. concluded that shadowing enhances several aspects of speaking including accuracy in production of reduced forms, connected speech, and prosody [42]. A shadowing study by Mochizuki using materials from an EFL textbook showed improvements in standardized speaking test results after six classes [43]. With studies demonstrating overall improvements seen through test results, as well as specific improvements in aspects such as speech rate, pitch, prosody, and connected speech, shadowing clearly has potential to improve learners' speaking proficiency.

Research has also been conducted on how to implement shadowing practice. Nakayama and Suzuki found that self-monitored shadowing led to improvements in shadowing performance when compared with pair-monitored shadowing [44]. Mori demonstrated that combining shadowing with oral reading improved English rhythm, intonation, and final lengthening [45]. The double blind study by Bovee and Stewart using native-speaker raters, concluded that shadowing is more effective for low-level learners of English and contended that a "ceiling effect" limits "the degree to which midand high-level students could improve" [34] (p. 894). More research that focuses on how shadowing practice can be adapted effectively for varying speaking proficiency levels could provide practical insights for learners and educators.

Other scholars point to the benefits of shadowing for improving listening comprehension. Hamada, in a study of 43 Japanese university level students, concluded that phoneme perception improved through nine lessons including shadowing practice [46]. Tamai's studies determined that in comparison to transcription, shadowing practice helped students obtain higher scores on listening comprehension tests [47], and that students in lower levels demonstrate more gains from shadowing than those in higher levels [48]. In a study with 41 students working to acquire an Aviation English Proficiency Test qualification, Kato saw improved TOEIC listening test scores after 5 months of shadowing (weekly $15 \mathrm{~min}$ shadowing sessions) [49]. While these studies focus on proficiency test score improvement, students' perceptions of improvements of their own listening ability are lacking, as are studies of improvement for the type of listening comprehension needed for conversation.

The impact of shadowing practice on overall language learning is also being studied, with Japan becoming one of the core sites for such investigations. Kadota reported that shadowing helps increase the capacity of the working memory [50]. Nakayama and Armstrong examined how the priming effect can stimulate the recall of previously learned material when shadowing [51]. Recent studies have been focused on fine-tuning and identifying best practices in shadowing pedagogy, and discovering techniques of reducing anxiety and improving motivation through the practice of shadowing [38].

\subsection{Motivation}

Although scholars disagree about what and how different factors intertwine over time and space to affect second language acquisition, the literature points to internal factors such as age, personality, intrinsic motivation, experience, cognition, and native language. External factors include method of instruction, curriculum, power relationships, extrinsic motivation, and access to L2 speakers [52]. While intrinsic and extrinsic motivation are not the only variables that influence language gain, and they certainly do not capture the entire story of one person's process of language acquisition, research 
has suggested that motivation is a predictor of success in language learning [53], as it both sparks and sustains the learning process [17]. Some scholars view motivation as equal in importance to language aptitude [54].

Since Gardner and Lambert's seminal work in the Canadian context [55], SLA motivation has been a focus of extensive scholarly attention. This research is often separated into three overlapping periods: the social psychological period (1959-1990), the cognitive-situated period (late 1980s-2000), and the socio-dynamic period (around 2000-Present) [56].

The social-psychological period is characterized by theorizing based on Gardner's research situated in Montreal where a perceived ethno-linguistic divide between French and English speakers was noted. In his theories, successful language learning is influenced by integrativeness, or the desire to identify with or integrate into the cultural community of the target language. This integrative process forms a key part of Gardner and Smythe's Socio-Educational Model of Second Language Acquisition, which characterizes the types of theories developed in this period [57]. Later in this period, instrumentality, the pragmatic gains that learning a language brings such as future jobs or higher salary, were added as a secondary dimension to the theory.

Commonly referred to as the "educational shift" in motivation, in the late 1980s and 1990s, scholars, such as Crookes and Schmidt [58], influenced by work in educational psychology, argued that the social-psychological perspective did not adequately depict the entirety of SLA motivation. Researchers suggested that the classroom atmosphere had a significant impact and added education-oriented approaches into theorizing. The micro-components of this analysis included the organization courses, effectiveness of teaching methods, and relevance of tasks. Cognitive aspects of motivation related to learners' view of their "self" were also introduced to the examination of motivation. For example, in one representative theory from the period, self-determination theory (SDT) [59], motivation is comprised of intrinsic, extrinsic, and integrative dimensions. In Noels' conception of SDT, motivation has external, intrinsic, and amotivational orientations. In studies based on her theory, she has found that "the key to fostering university-level students' motivation is by supporting the development of their autonomy and their competence in language learning" plus a plan of action where students can check their progress [15] (p. 26).

In the late 1990s, academic thought on motivation began to integrate notions of power relations. Norton Peirce, noting that existing concepts of motivation did not "capture the complex relationship between relations of power, identity, and language learning" [60] (p. 17), argued that investment, which acknowledges a learner's multiple identities that change over time and space, captures a language learner's desire to speak more effectively than motivation. A learner invests in language learning knowing that they will gain resources that will enhance their cultural capital and social power.

The socio-dynamic period, the most recent period in SLA motivation research, takes into consideration critiques, including Norton Peirce's, that motivation is fluid and changing depending on time and space and is influenced by structures of power. In addition to classroom variables, the importance of a learner's personal and social experience and attributes is recognized. Dörnyei's L2 Motivational Self-System, representative of the Socio-dynamic Period, considers how dimensions of ideal L2 self, the ought-to L2 self, and L2 learning experience interact in developing a person's SLA motivation [17].

\subsection{Motivation Research in Japan}

Recently, a significant number of theoretical and empirical studies on motivation have been undertaken in Japan in the university context. Ryan's study aimed to validate Dörnyei's L2 Motivational Self system [21] and Irie and Brewster [61] reported preliminary findings of their longitudinal study examining how ideal L2 self serves as a guide in language learning. Munezane found in her quantitative studies that connecting learners to their ideal self in the classroom has positive impacts on motivation [62]. Therefore, expanding research to identify effective methods for connecting students with their ideal L2 selves in and outside of the classroom could prove beneficial. 
The influence of anxiety, or the feeling of apprehension about using a foreign language, on language learning and motivation is another highly relevant variable in the Japanese context. In Japan, even amongst highly motivated and diligent students, high levels of apprehension about communicating in English are viewed as one of the major, if not the strongest, barriers to willingness to communicate in English [63]. Feelings of negative anxiety about speaking were also found to predict willingness to communicate and achievement [17,64-67]. Studies on foreign language anxiety in Japan have included explorations into which situations cause anxiety [68] and how anxiety is linked to motivation [69]. Research on practical techniques for learners to identify their own levels of anxiety and overcome the hurdles anxiety brings to the process of language learning is lacking.

Other variables of interest that have a correlation with motivation include linguistic self-confidence and attitudes towards the L2 [70]. Linguistic self-confidence refers to a learner's belief in their ability to become proficient in a target language and is related to the quality of contact with the language [71]. Since the study of English in Japan entails minimum contact with English-speaking communities, it is an important factor to consider. A longitudinal study of Japanese university students found that low linguistic self-confidence had a negative influence on motivation [72]. While proven to be an important factor, further study-specific techniques for improving a student's linguistic self-confidence are lacking. Attitudes towards learning English also influence language acquisition with positive attitudes viewed as a predictor of language learning success, and negative attitudes shown as having a negative impact on language learning $[13,16]$. While proven to be an important factor, practical studies on how these attitudes change over time based on learning experiences are needed.

\subsection{Motivation and Science and Engineering Majors}

Several studies have evaluated the L2 motivation of engineering and science majors. In one survey including 397 tertiary-level students, the researchers concluded that engineering majors study English for more pragmatic reasons than those who expressed a need for English in the future [73]. In terms of differences between first-year science and engineering majors classified into high proficiency (HP) and low proficiency (LP) groups, Falout and Maruyama concluded that both proficiency groups showed favorable attitudes to the English-speaking community and attribute their demotivation to disappointment in performance, course content and pace, and teacher's pedagogical approach [74]:

LP students more often internalized the causes of their demotivation. HP students showed more control over their affective states and learning situations. They especially despised the pedagogy of humiliation, though both sets vented most about teachers. [74] (p. 7)

A pedagogy that does not focus on pointing out learners' mistakes, but instead allows them independence to self-correct and learn at their own pace may be effective in countering demotivation.

Additionally, anecdotal evidence suggests that teachers tend to assume that S\&E majors do not "like" English. These results add evidence that suggests otherwise- they might feel demotivated, but that does not mean they do not have positive attitudes towards the English-community. Finally, Apple's study found that S\&E students tended to show an interest in communicating in English, but believe their speaking ability to be below average, and have relatively high anxiety towards English used in the classroom. He also concluded that for S\&E majors, ought-to L2 self has more of an impact on L2 achievement than ideal and future selves [75]. Based on the results of Kaneko's study of 38 undergraduate science majors who experienced seminars in English conducted by Japanese scientists, she suggested that helping students "form a clearer image of their Ideal L2 self" by providing Japanese role models could improve motivation [76] (p. 21). The results of these studies cannot necessarily be generalized to apply to all S\&E majors, but do suggest some tendencies. Based on these results, however, more research on how to tailor pedagogy to the varying needs of science and engineering students is necessary.

Identifying and assessing teaching strategies, techniques, and pedagogies can have a positive influence on student motivation and learning. Bernaus and Gardner concluded after a study of students' 
perceptions of teacher strategies that, in order for "strategies to be effective in influencing students' motivation they must be perceived as such by the students. We recommend, therefore, that teachers assess their students' perceptions of any strategies they employ" [16] (p. 399). This assessment can be used to guide teachers in developing effective materials for each teaching context. Developing teaching methods that diminish or eliminate anxiety-causing situations and enhance self-efficacy can benefit language learners in Japan.

\subsection{Motivation and Mobile-Assisted Language Learning}

Research on the influence of MALL on motivational change, however, is limited. One study using a Funds of Knowledge approach found that motivation to write increased using a digital hand writing application on i-Pads (Apple Inc.) [77]. Researchers studying the responses of 60 ESL undergraduates' engagement with the Taplingua (Taplingua SL, Madrid, Spain) application for listening and exercises for grammar and vocabulary inferred that motivation increased with frequency of use of the application as the semester progressed [19]. A study at a Romanian medical university specifically asked students how they believed MALL would enhance their motivation. Responses pointed to accessibility, the informal nature of MALL in making learning fun, and benefits of students controlling their own learning [78]. While these studies incorporated analysis on student achievement, they fail to assess specific variables that cause the "self" to take action.

\subsection{Motivation and Shadowing}

There is also room for more inquiry into how the practice of shadowing is related to motivation. Several studies have noted that post-shadowing has the potential to decrease anxiety and increase motivation. The two Japanese adult participants in one study reported improved listening and speaking proficiency and lower anxiety levels through a hybrid read aloud plus shadowing methodology [18]. Another mixed methods study by Hamada in which eight Japanese sophomores were interviewed found that initial motivation levels in intermediate learners of English were critical in determining how much a learner was motivated by shadowing. Based on these results, he suggested that allowing students to consistently "check their improvement would enhance the effectiveness of shadowing training" [79] (p. 19). In a 5-week mixed-methods study in Taiwan with 25 high school students, the researcher concluded that shadowing enhanced students' attitudes towards learning English and self-confidence towards speaking English. Although several thought shadowing to be boring, the students recognized it as a way for them to improve their English [80]. Studies with greater numbers of participants and a longer period of time that shadowing is practiced can shed further light on the impact of shadowing on motivation.

\section{Materials and Methods}

\subsection{Participants}

The participants in this study were 1001 first-year university students at a university in Japan, ages ranging from 18 to 23 , mostly majoring in the sciences (engineering (30\%); medicine (19\%), economics $(10 \%)$, agriculture $(12 \%)$. Only $29 \%$ of the participants majored in the liberal arts (literature, humanities, law and education) (see Figure 1). In total, $72 \%$ of the participants identified as male and $28 \%$ as female. In total, $97 \%$ identified as Japanese. In total, $36 \%$ of the participants had visited an English-speaking country with only $5 \%$ staying longer than three months. In terms of contact with English, $72 \%$ of the students never encountered English speakers outside of class. Outside of class, $76 \%$ listen to English media less than $30 \mathrm{~min}$ a week and $61 \%$ listen to English music less than $30 \mathrm{~min}$ a week. The general curriculum did not require listening comprehension-focused classes. After the study was introduced, the participants provided informed consent and were given the option to remove themselves from the study at anytime. 
The university where the study took place is a highly competitive research-oriented university maintaining the second highest ranking in Japan, and an average hensachi of 72.2 [81]. Hensachi is an indicator of the difficulty of the entrance exams for a university department compared to all universities nationwide. The average hensachi for universities is around 50 with the highest at 80 and the lowest at 34 . While the university has not conducted a comprehensive study of students' English proficiency levels, based on unofficial calculations, TOEFL-ITP scores at the university are an average of 78 out of 120, with an average writing score of 22 out of 30 [82]. The average scores for the listening and reading sections of TOEIC summer intensive courses at the university from 2011 to 2014 were 56.37 and 65.39 respectively [11].

\subsection{Shadowing Application Description}

In order to address the issue of student access to listening comprehension materials for practice, researchers at the university developed a shadowing application accessible via smart phones, computers, and tablets $[11,20]$. The shadowing application provides students with materials through their devices, enabling them to practice shadowing at their own convenience without having to make extra time to go to a computer lab at the university. It is also hypothesized that students will start to feel less anxiety towards learning English since the shadowing system allows students to practice listening and speaking where learners want instead of in the classroom which, according to Apple, can trigger anxiety in some S\&E majors [75].

When students log into their class on the app, a list of shadowing materials assigned to them appears. After selecting a shadowing exercise, they are brought to a screen which shows them the name of the material, gives them an option for showing or hiding the script, a play and stop button for playing the shadowing material, and a record button for recording the student's voice as they shadow (see Figure 2). Students can record themselves shadowing the material as many times as they want and a graph of their pitch is generated for each recording. Students listen to the recording through earphones that have a microphone attached to capture their utterances. After students record themselves shadowing, they can play back and listen to their voice. As Hamada noted [79], this type of self-monitoring may help students develop autonomy, enhancing the efficacy of the shadowing practice. Multiple recordings can be made of the same material and students can choose which recording to submit to their teacher.

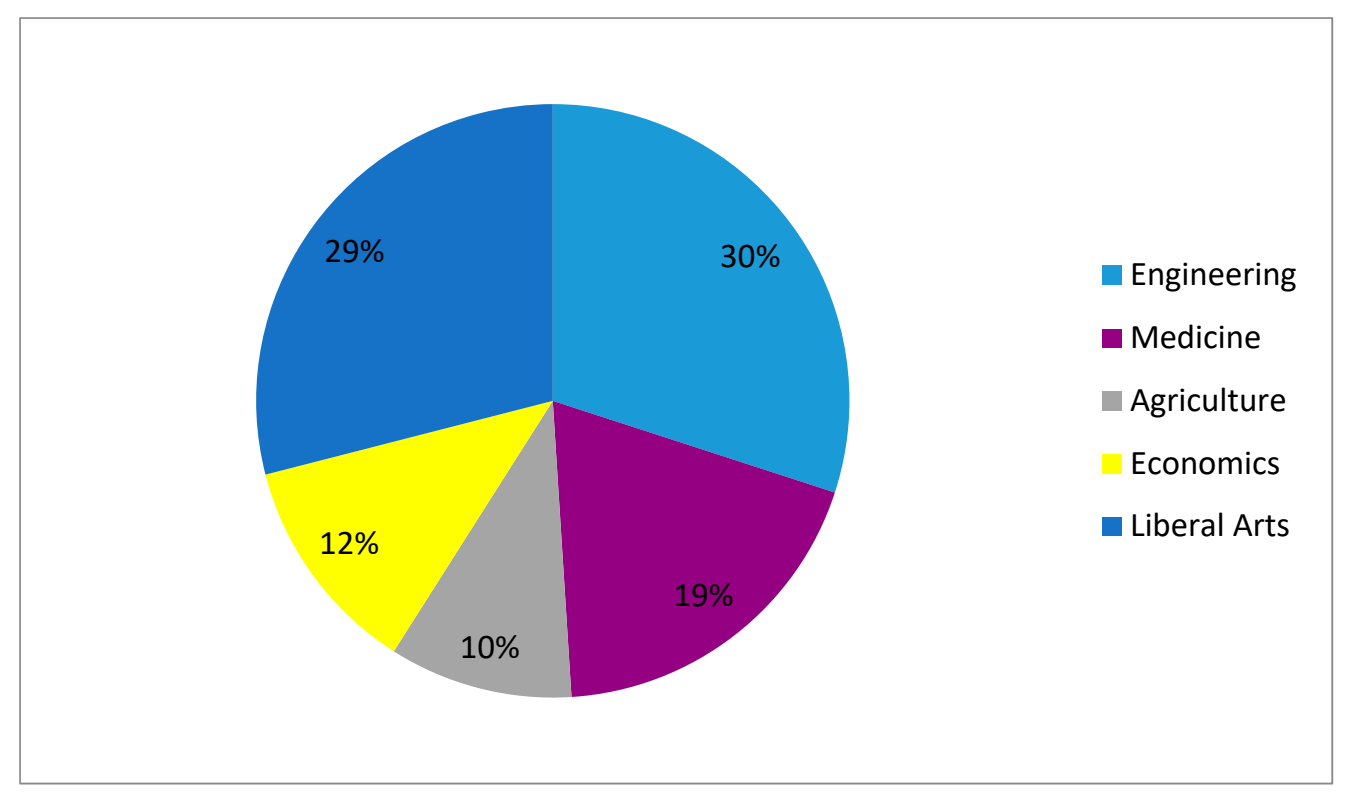

Figure 1. Percentage of participants by major. 


\subsection{Shadowing Intervention}

Four teachers in charge of a total of 30 academic writing classes which met weekly, with an average of 37 students each, assigned students shadowing homework weekly to complete outside of class through their shadowing application on their tablets, smart phones, or computers. In order to gauge listening comprehension gains by use of the shadowing system, the lead researcher on the team Kayoko Ito, conducted as a pre-intervention and post-intervention TOEIC practice listening tests to examine how students' proficiency levels changed. Results indicate that if students practiced shadowing for over an hour a week, their TOEIC test scores improved $(t=1.96, p=0.05)$. Furthermore, students who first registered high scores on the tests maintained their high scores [11,20]. This is significant because university students' standardized test scores tend to decrease after their first year $[8,9]$. In other words, the results suggest that the shadowing intervention might have had an impact on students maintaining or improving their scores since most students were not taking additional listening comprehension classes.

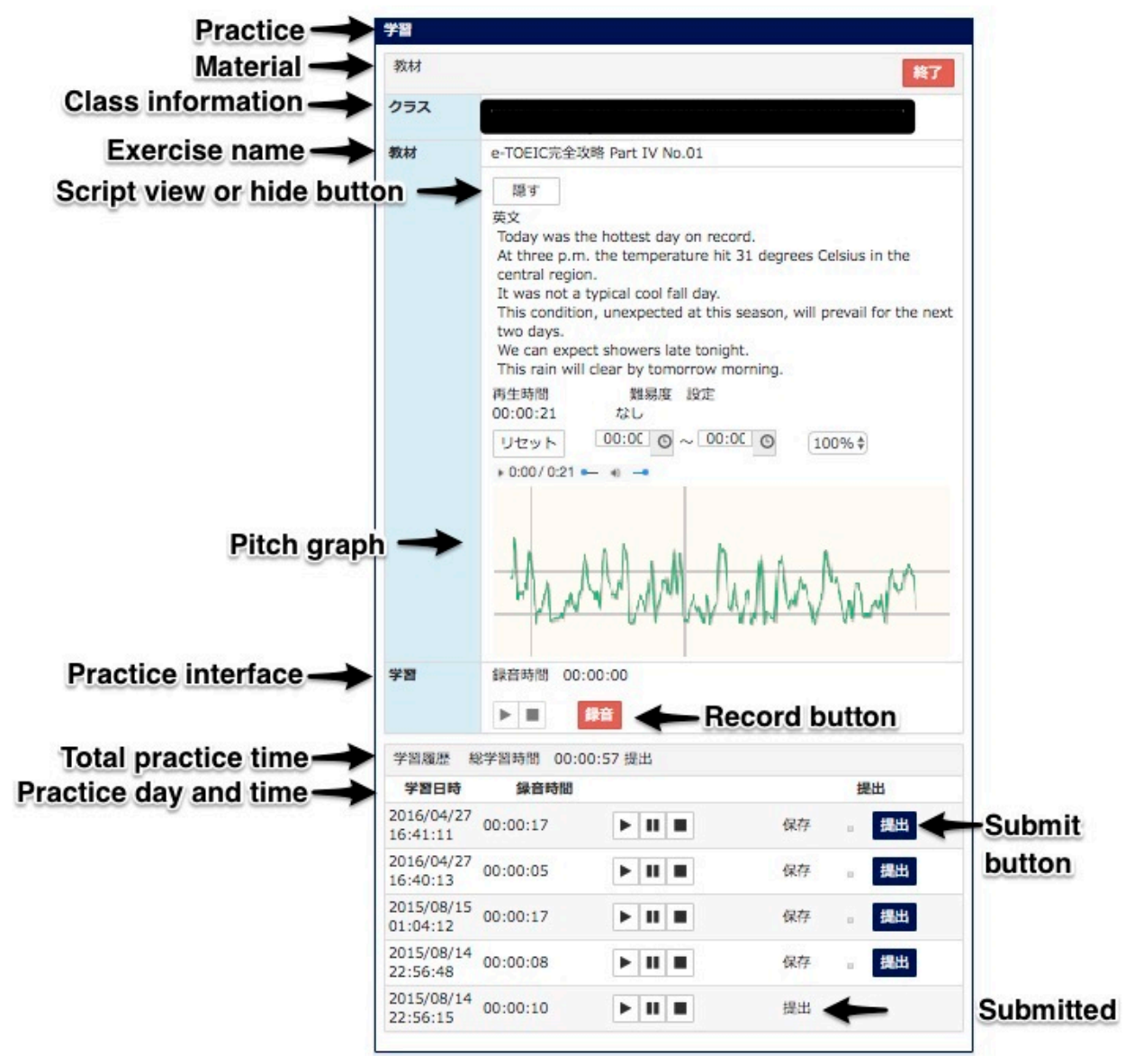

Figure 2. Shadowing recording screen with English translation.

Following the pre-intervention TOEIC test, the shadowing system was introduced to students in class. Students were taught how to login, download necessary extensions for the system, and do pre- and post-shadowing. They were also taught how to maneuver the interface which included locating the shadowing material to be studied, listening to the shadowing material, reading the script for the shadowing material, making recordings of their shadowing, listening to their recordings, and submitting shadowing recordings to their teacher. Most of the students were taking classes in CALL classrooms, with the exception of ten classes. For students in CALL classrooms, students accessed the shadowing system through Windows computers with microphones attached. 
Over 12 weeks, from April to July 2015, students were assigned five different shadowing materials weekly and asked to submit their what they considered their best shadowed recordings for each material to their teacher through the shadowing system. The shadowing materials originated from texts produced to help learners prepare for Section 3 (short conversations) and Section 4 (short talks) of TOEIC with agreement from the publishers. Below is an example of one of the shadowing materials [83] (p. 57):

Man: Excuse me, ma'am. I'd like to open a checking account here and make about a $\$ 30,000$ deposit. Please tell me what to do.

Woman: Just fill out this form, but with that amount, you may want to put a part of it into a certificate of time deposit. It'll give you a much higher interest rate.

Man: I see. That's a kind of savings account, right?

Woman: That's correct, but you leave the money in the account for a set period of time, from three months up to several years. You shouldn't take it out until it matures, or there will be a penalty.

Man: OK, then, I'll put $\$ 20,000$ into one of those and the remaining $\$ 10,000$ in checking.

Question: What does the woman recommend the man do?

Students were also encouraged, though not required, to do additional shadowing practice with other uploaded materials whether they were teacher-uploaded or other materials made available to all students for the TOEIC test and Eiken test, an English proficiency test specific to Japan. In accordance with Noels' suggestion for enhancing student motivation [15], providing both student autonomy and a teacher-guide in this manner, may enhance student engagement. All shadowing materials were up to one minute in length, and included American, Australian, and UK varieties of English.

Students were allowed to proceed in their shadowing practice with pre-shadowing or post-shadowing, and with or without viewing the scripts. Similar to the Foote and McDonough study [39], the students were allowed to choose their favored method of shadowing practice to more accurately simulate how students would shadow if not in a research study.

\subsection{Instrumentation}

This study used post-task protocol analysis, as suggested by Murphey [37] which helps elucidate how learners evaluate their ability after practicing shadowing over a prolonged period of time. A 47-item questionnaire in Japanese was administered to students prior to and after 14 weeks of shadowing study through SurveyMonkey (www.surveymonkey.com). All items besides those asking for demographic data and study time were formatted as six-point Likert scale $(1=$ strongly disagree; 2 = disagree; 3 = slightly disagree: $4=$ partly disagree $5=$ agree; $6=$ strongly agree) questions with no neutral option.

The scales for the questionnaire (see Appendix A) were adapted from previously administered and tested surveys exploring the L2 Self-Motivation System but instead of asking about English overall, the items were framed to ask specifically about listening comprehension. Items were adapted from Taguchi et al. [84], Suzuki et al. [85], and Ryan [21]. The number of items per hypothetical construct was:

Instrumental (I) (6).

Linguistic self-confidence (LSC) (4).

Anxiety (A) (5).

Attitudes towards listening comprehension practice in the L2 (1).

Interest in oral communication in the L2 (IL) (6).

Ideal L2 self (ILS) (9). 
In addition to these items, questions regarding how often students meet speakers of English, hear English spoken in the media, and listen to music in English were included. There were also questions regarding

1. Number of friends and family who speak English;

2. Experience in foreign countries, both English-speaking and not-English speaking;

3. Self-assessed level of listening and speaking proficiency;

4. Past and intended time studying English; and

5. Gender.

An additional seven items were added to the post-intervention questionnaire to gauge students' enjoyment of the practice of shadowing, perception of its efficacy for improving listening comprehension, and intention to use shadowing in the future. A question asking students to report how much shadowing practice they completed every week was also added.

The pre-intervention survey was administered during the first week of class. The post-shadowing survey was administered during the 14th week of class. Students who had access to computers in the classroom completed the survey at the end of class, while those with no access completed the surveys during or outside of class on their mobile phones or own computers, depending on the teacher's instructions. An auto-generated compilation of the survey results appeared on respondents' displays immediately after completion of the survey.

\section{Analytical Procedures and Results}

\subsection{Analytical Procedures}

After removing responses from students that did not identify as Japanese $(n=18)$ and cases due to missing data, the responses of 949 participants for the pre-test and 747 for the post-test were analyzed with SPSS. Since individual identification numbers were not given, the data was treated as two separate groups to be compared.

Several tests were conducted on the pre- and post- intervention data:

1. Independent samples $t$-tests to examine if there were significant changes over time in motivation and attitudes.

2. Independent sample $t$-tests on constructs of motivation and attitudes.

3. Independent samples $t$-tests on perceptions of English speaking and listening proficiency.

4. Cross tabulation to determine how contact with English changed during research period.

5. Spearman's correlations on all items.

6. Descriptive statistics on additional items in post-test related to shadowing.

7. Reliability analysis with cross tabulation.

\subsection{Changes in Motivation and Attitudes: Items}

Initially, a series of independent-samples $t$-tests were conducted on all individual items in order to determine whether means of these items significantly changed over time. These tests were conducted on all the items associated with the constructs above (see Appendix A for the instrument, arranged by construct).

Within this section, for readability, only those tests found to achieve statistical significance will be discussed. While no significant results were found with respect to the Instrumental construct, three significant results were found with regard to the linguistic self-confidence (LSC) construct and one with regard to the anxiety (A) construct (see Table 1). Here, significant mean differences were found with regard to Question 7 ("English listening comprehension is easy"), $t(1570.53)=-3.36, p<0.01$, Question 9 ("I am good at English learning English"), $t(1631.56)=-2.75, p<0.01$, and Question 20 (“I know effective ways to study English listening comprehension"), $t(1694)=-4.27, p<0.001$. In all 
of these items, there was a significantly higher mean in the post-test in comparison with the pre-test. With regard to the anxiety questions, statistical significance was found with regard to Question 10 ("I feel like other students in my class are better than me at English"), $t(1694)=2.648, p<0.01$ and the mean was higher in the pre-test.

Additionally, three significant results were found with regard to the questions relating to interest in oral communication in the L2 (IL) ((see Table 2). Specifically, a significant mean difference was found in relation to Question 11 ("I get excited when my teacher speaks to the class in English"), $t(1663.210)$ $=-1.981, p<0.05$, Question 31 ("I really want to be able to understand spoken English"), $t(1694)$ $=2.428, p<0.05$, and Question 32 ("Being able to understand spoken English is important to me"), $t(1694)=3.300, p<0.01$. Significantly higher means were found in the post-test for Question 11, while significantly lower means were found in the post-test for Questions 31 and 32.

With respect to ideal L2 self (ILS), significance was found in relation to Question 21 ("I believe I will be able to understand spoken English with little difficulty if I keep practicing listening comprehension"), $t(1640.069)=-2.420, p<0.05$, and Question 24 ("I can image myself speaking English to other English speakers like a fluent speaker in 2 years"), $t(1694)=-2.359, p<0.05$. Significantly higher means were found in the post-test in Questions 21 and 24. 
Table 1. Linguistic Self-Confidence (LSC) and Anxiety (A) items pre- and post-test.

\begin{tabular}{|c|c|c|c|c|c|c|c|c|c|c|}
\hline & & \multicolumn{2}{|c|}{$\begin{array}{c}\text { Levene's Test for Equality } \\
\text { of Variances }\end{array}$} & \multicolumn{7}{|c|}{$t$-Test for Equality of Means } \\
\hline & & \multirow{2}{*}{$\mathrm{F}$} & \multirow{2}{*}{ Sig. } & \multirow{2}{*}{$t$} & \multirow{2}{*}{$\mathrm{df}$} & \multirow{2}{*}{$\begin{array}{c}\text { Sig. } \\
\text { (2-Tailed) }\end{array}$} & \multirow{2}{*}{$\begin{array}{c}\text { Mean } \\
\text { Difference }\end{array}$} & \multirow{2}{*}{$\begin{array}{c}\text { Std.Error } \\
\text { Difference }\end{array}$} & \multicolumn{2}{|c|}{$95 \%$ Confidence Interval of the Difference } \\
\hline & & & & & & & & & Lower & Upper \\
\hline \multirow{2}{*}{$\begin{array}{l}\text { 7. English listening comprehension is } \\
\text { easy (LSC) }\end{array}$} & $\begin{array}{c}\text { Equal variances } \\
\text { assumed }\end{array}$ & 4.02 & 0.05 & -3.38 & 1694 & 0.001 & -0.18 & 0.05 & -0.28 & -0.07 \\
\hline & $\begin{array}{l}\text { Equal variances not } \\
\text { assumed }\end{array}$ & & & -3.36 & 1570.53 & 0.001 & -0.18 & 0.05 & -0.28 & -0.07 \\
\hline \multirow{2}{*}{ 9. I am good at learning English (LSC) } & $\begin{array}{l}\text { Equal variances } \\
\text { assumed }\end{array}$ & 6.67 & 0.01 & -2.73 & 1694 & 0.006 & -0.15 & 0.05 & -0.26 & -0.04 \\
\hline & $\begin{array}{l}\text { Equal variances not } \\
\text { assumed }\end{array}$ & & & -2.75 & 1631.56 & 0.01 & -0.15 & 0.05 & -0.26 & -0.04 \\
\hline \multirow{2}{*}{$\begin{array}{l}\text { 20. I know effective ways to study } \\
\text { English listening comprehension } \\
\text { (LSC) }\end{array}$} & $\begin{array}{l}\text { Equal variances } \\
\text { assumed }\end{array}$ & 0.061 & 0.81 & -4.27 & 1694 & 0.000 & -0.24 & 0.06 & -0.35 & -0.13 \\
\hline & $\begin{array}{c}\text { Equal variances not } \\
\text { assumed }\end{array}$ & & & -4.27 & 1599.22 & 0.000 & -0.24 & 0.06 & -0.35 & -0.13 \\
\hline \multirow{2}{*}{$\begin{array}{l}\text { 10. I feel like other students in my } \\
\text { class are better than me at English (A) }\end{array}$} & $\begin{array}{l}\text { Equal variances } \\
\text { assumed }\end{array}$ & 0.03 & 0.86 & 2.65 & 1694 & 0.008 & 0.17 & 0.07 & 0.05 & 0.3 \\
\hline & $\begin{array}{c}\text { Equal variances not } \\
\text { assumed }\end{array}$ & & & 2.65 & 1596 & 0.008 & 0.17 & 0.07 & 0.05 & 0.3 \\
\hline
\end{tabular}


Table 2. Interest in the L2 (IL) and ideal L2 self (ILS) items pre- and post-test.

\begin{tabular}{|c|c|c|c|c|c|c|c|c|c|c|}
\hline & & \multicolumn{2}{|c|}{$\begin{array}{c}\text { Levene's Test for Equality } \\
\text { of Variances }\end{array}$} & \multicolumn{7}{|c|}{$t$-Test for Equality of Means } \\
\hline & & \multirow{2}{*}{$\mathrm{F}$} & \multirow{2}{*}{ Sig. } & \multirow{2}{*}{$t$} & \multirow{2}{*}{ df } & \multirow{2}{*}{$\begin{array}{c}\text { Sig. } \\
\text { (2-Tailed) }\end{array}$} & \multirow{2}{*}{$\begin{array}{c}\text { Mean } \\
\text { Difference }\end{array}$} & \multirow{2}{*}{$\begin{array}{c}\text { Std.Error } \\
\text { Difference }\end{array}$} & \multicolumn{2}{|c|}{$95 \%$ Confidence Interval of the Differenc } \\
\hline & & & & & & & & & Lower & Upper \\
\hline \multirow{2}{*}{$\begin{array}{l}\text { 11. I get excited when my teacher } \\
\text { speaks to the class in English (IL) }\end{array}$} & $\begin{array}{c}\text { Equal variances } \\
\text { assumed }\end{array}$ & 18.67 & 0.00 & -1.96 & 1694 & 0.05 & -0.12 & 0.06 & -0.25 & -0.00 \\
\hline & $\begin{array}{l}\text { Equal variances not } \\
\text { assumed }\end{array}$ & & & -1.98 & 1663.21 & 0.05 & -0.12 & 0.06 & -0.25 & -0.00 \\
\hline \multirow{2}{*}{$\begin{array}{l}\text { 31. I really want to be able to } \\
\text { understand spoken English (IL) }\end{array}$} & $\begin{array}{c}\text { Equal variances } \\
\text { assumed }\end{array}$ & 0.16 & 0.69 & 2.43 & 1694 & 0.02 & 0.14 & 0.07 & 0.03 & 0.25 \\
\hline & $\begin{array}{c}\text { Equal variances not } \\
\text { assumed }\end{array}$ & & & 2.44 & 1633.97 & 0.02 & 0.14 & 0.06 & 0.03 & 0.25 \\
\hline \multirow{2}{*}{$\begin{array}{l}\text { 32. Being able to understand spoken } \\
\text { English is important to me (IL) }\end{array}$} & $\begin{array}{c}\text { Equal variances } \\
\text { assumed }\end{array}$ & 1.38 & 0.24 & 3.3 & 1694 & 0.00 & 0.18 & 0.05 & 0.07 & 0.29 \\
\hline & $\begin{array}{l}\text { Equal variances not } \\
\text { assumed }\end{array}$ & & & 3.32 & 1631.93 & 0.00 & 0.18 & 0.05 & 0.07 & 0.29 \\
\hline \multirow{2}{*}{$\begin{array}{l}\text { 21. I believe I will be able to } \\
\text { understand spoken English with little } \\
\text { difficulty if I keep practicing listening } \\
\text { comprehension (ILS) }\end{array}$} & $\begin{array}{c}\text { Equal variances } \\
\text { assumed }\end{array}$ & 3.951 & 0.05 & -2.4 & 1694 & 0.02 & -0.14 & 0.06 & -0.26 & -0.03 \\
\hline & $\begin{array}{l}\text { Equal variances not } \\
\text { assumed }\end{array}$ & & & -2.42 & 1640.07 & 0.02 & -0.14 & 0.06 & -0.26 & -0.03 \\
\hline \multirow{2}{*}{$\begin{array}{l}\text { 24. I can image myself speaking } \\
\text { English to other English speakers like } \\
\text { a fluent speaker in } 2 \text { years (ILS) }\end{array}$} & $\begin{array}{c}\text { Equal variances } \\
\text { assumed }\end{array}$ & 0.03 & 0.86 & -2.36 & 1694 & 0.02 & -0.13 & 0.05 & -0.23 & -0.02 \\
\hline & $\begin{array}{c}\text { Equal variances not } \\
\text { assumed }\end{array}$ & & & -2.36 & 1613.07 & 0.02 & -0.13 & 0.05 & -0.23 & -0.02 \\
\hline
\end{tabular}




\subsection{Changes in Motivation Analyzed by Construct}

The constructs were then analyzed by calculating the means of the constituent items in SPSS, with independent-samples $t$-tests then conducted in order to determine whether there were significant mean differences between the pre-test and post-test scores associated with these constructs (Figure 3). Here, statistical significance was found with respect to instrumental questions, $t(1371.228)=-10.999$, $p<0.001$ and linguistic self-confidence, $t(1694)=-4.272, p<0.001$. Significantly higher means in the post-test were found in the cases of instrumental questions and linguistic self-confidence.

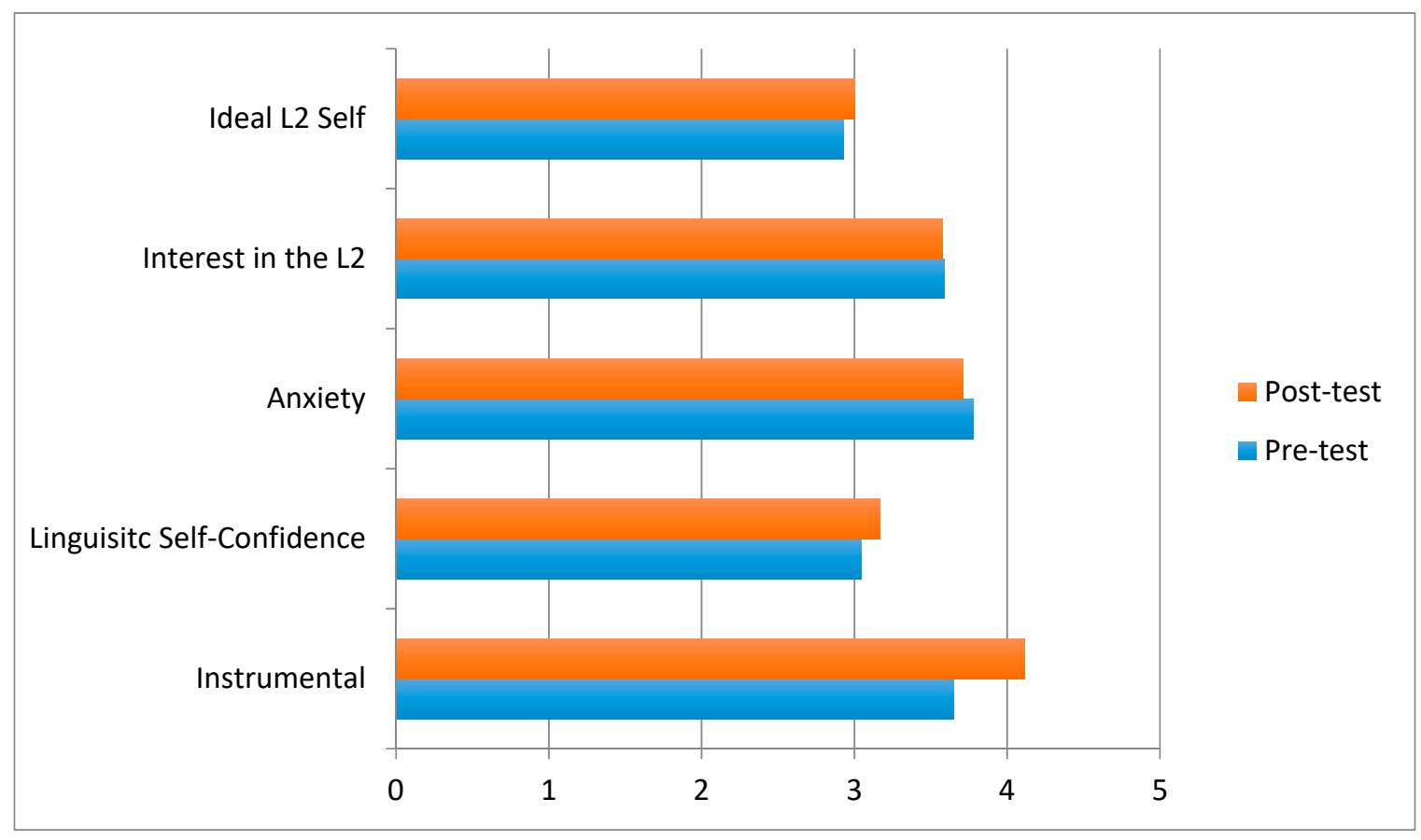

Figure 3. Pre- and post-test means by construct.

\subsection{English Speaking and Listening Proficiency and Contact with English}

Two additional analyses were conducted on these data. First, independent-samples $t$-tests were conducted in order to determine whether there was a significant increase in English proficiency rating over time. This $t$-test was found to achieve statistical significance, $t(1626.538)=4.171, p<0.001$, with the descriptive statistics associated with these measures indicating that self-rated proficiency significantly improved over time. Additionally, a cross tabulation was conducted between how often respondents met speakers of English comparing pre-test and post-test scores. The results of this analysis indicated that responses to this measure only changed minimally between pre-test and post-test administrations of the survey.

\subsection{Correlations}

A series of additional Spearman's correlations were conducted to assess the relationship between self-reported frequency of shadowing ("How much time did you practice shadowing every week this semester?") and all of the items in the survey. With respect to this set of correlations, statistical significance was found with respect to the majority of the variables. Specifically, statistical significance was found in relation to all items except for Questions 8, 10,16, and 18. Primarily, only questions that registered weak to strong correlations will be reported here.

All instrumental questions items reported correlations of weak to moderate. Linguistic self-confidence items Question 9 ("I am good at learning English"), $\varrho=0.136, p<0.001$ and Question 20 ("I know 
effective ways to study English listening comprehension"), $\varrho=0.177, p<0.001$ registered weak to moderate correlations.

Interest in communication in the L2 questions also registered weak to moderate correlations: Question 11 ("I get excited when my teacher speaks to the class in English"), $Q=0.224, p<0.001$; Question 13 ("I get excited when my teacher speaks to me in English"), $\varrho=0.242, p<0.001$; Question 15 ("I get excited when English is spoken to me by other people from my country speak to me in English"), $\varrho=0.186, p<0.001$; Question 18 ("I get excited when English is spoken to me by foreigners"), $\varrho=0.191$, $p<0.001$, ); Question 31 ("I really want to be able to understand spoken English"), $Q=0.209, p<0.001$, and Question 32 ("Being able to understand spoken English is important to me"), $\varrho=0.230, p<0.001$.

For anxiety items, negative, very weak to weak correlations were found for Question 12 ("I get uneasy when my teacher speaks to the class in English"), $\varrho=-0.077, p<0.01$ and Question 14 ("I feel uneasy when English is spoken to me by other people from my country"), $\varrho=-0.067, p<0.01$. The more students shadowed, the more their anxiety in relation to these items decreased.

Positive weak to moderate correlations were also found with most ideal L2 self items: Question 21 ("I believe I will be able to understand spoken English with little difficulty if I keep practicing shadowing"), $\varrho=0.147, p<0.001$; Question 22 ("I can imagine myself listening to news in English with little difficulty 2 years from now"), $\varrho=0.207, p<0.001$; Question 23 ("I can imagine myself listening to new in English with little difficulty 4 years from now"), $\varrho=0.242, p<0.001$; Question 24 ("I can imagine myself speaking English to other English speakers like a fluent speaker in 2 years"), $\varrho=0.176$, $p<0.001$; Question 25 ("I can imagine myself speaking English to other English speakers like a fluent speaker in 4 years"), $\varrho=0.231, p<0.001$; Question 26 ("I can imagine myself speaking and listening to English with little difficulty"), $\varrho=0.239, p<0.001$; Question 27 ("I can imagine myself using English in a variety of ways in two years"), $\varrho=0.200, p<0.001$; Question 28 ("I can imagine myself using English in a variety of ways in 4 years"), $\varrho=0.234, p<0.001$, and Question 29 ("I can imagine myself being able to understand almost all spoken English in the future), $\varrho=0.196, p<0.001$ ).

For attitudes towards listening comprehension and shadowing, the items with weak to moderate correlations include Question 30 ("I really like doing listening comprehension practice"), $\varrho=0.292$, $p<0.001$; Question 36 ("Shadowing is interesting"), $\varrho=0.303, p<0.001$; Question 37 ("Shadowing is boring"), $\varrho=-0.164, p<0.001$; Question 38 ("My listening comprehension skills improved thanks to shadowing"), $\varrho=0.309, p<0.001$; Question 39 ("Shadowing is an effective technique for studying English"), $\varrho=0.266, p<0.001$; Question 40 ("Thanks to shadowing I want to do more listening comprehension practice"), $\varrho=0.319, p<0.001$. Of note, there was a very weak to weak correlation for Question 41 ("I find myself doing shadowing in my everyday life"), $Q=0.181, p<0.001$. A moderate to strong correlation was found with Question 42 (In the future, I want to use shadowing to practice listening comprehension), $\varrho=0.437, p<0.001$.Finally, improvements in English listening proficiency, $\varrho=-0.114, p<0.001$ were found with higher rates of shadowing (note the scale was opposite to the Likert scale—see Appendix A).

\subsection{Descriptive Statistics on Attitudes towards Shadowing Items}

Descriptive statistics were conducted on these data in order to provide a preliminary illustration of the data collected (Table 3). The items reported here are relevant to all students' perceptions of shadowing. It is important to note that it is likely that students who did less shadowing were less likely to report improved listening comprehension thanks to shadowing (Question 38). The median response to the item "Shadowing is interesting" was 3 (close to "Slightly Disagree" with the middle $50 \%$ falling between 2 and 4 on the scale. The medians for "Shadowing is boring," "Shadowing is an effective way of learning English," and "I want to use shadowing to practice listening comprehension in the future" were 4 (close to "Slightly Agree") with a range of 3 to 4. 
Table 3. Select attitudes towards shadowing.

\begin{tabular}{|c|c|c|c|c|c|}
\hline & & $\begin{array}{l}\text { 36. Shadowing } \\
\text { is Interesting }\end{array}$ & $\begin{array}{l}\text { 37. Shadowing } \\
\text { is Boring }\end{array}$ & $\begin{array}{l}\text { 39. Shadowing is an } \\
\text { Effective Way of } \\
\text { Learning English }\end{array}$ & $\begin{array}{l}\text { 42. In the Future, I Want to } \\
\text { Use Shadowing to Practice } \\
\text { Listening Comprehension }\end{array}$ \\
\hline \multicolumn{2}{|c|}{ Mean } & 2.9792 & 3.7403 & 3.8299 & 3.4766 \\
\hline \multicolumn{2}{|c|}{ Median } & 3.0000 & 4.0000 & 4.0000 & 4.0000 \\
\hline \multicolumn{2}{|c|}{ Std. Deviation } & 1.19038 & 1.22291 & 1.13160 & 1.21225 \\
\hline \multicolumn{2}{|c|}{ Range } & 5.00 & 5.00 & 5.00 & 5.00 \\
\hline \multirow{2}{*}{ Percentiles } & 25 & 2.0000 & 3.0000 & 3.0000 & 3.0000 \\
\hline & 75 & 4.0000 & 4.0000 & 4.0000 & 4.0000 \\
\hline
\end{tabular}

\subsection{Reliability Analysis}

In this survey, three sets of two items each were examined in order to help determine the reliability present within this study. Specifically, these pairs of items consisted of the following:

- Question 7 ("English listening comprehension is easy") and Question 8 ("English listening comprehension is difficult").

- Question 35 ("Shadowing is interesting") and Question 36 ("Shadowing is boring").

These analyses consisted of a series of cross tabulation tables and examined the correlation or association between responses to these sets of measures. First, with regard to English listening comprehension being easy or difficult, the focus was on individuals who agreed or disagreed to both questions, as these pairs of responses would indicate that the individual was perhaps not completing the survey consistently. In total, 155 respondents out of a total of 1769 , or $8.76 \%$ provided inconsistent responses. Finally, when comparing "Shadowing is interesting" and "Shadowing is boring," the number of inconsistent responses was determined to be 224 individuals out of a total of 770 , or $29.09 \%$. Overall, these results suggest some discrepancies with respect to individuals' responses to these survey items.

\section{Discussion}

Results of the data analysis suggest that students' linguistic self-confidence improved in relation to English listening comprehension and speaking. In addition to higher mean scores for the construct itself, there were also higher scores for three items measuring it. Furthermore, the post-test means for this construct were higher. While it could be argued that the general curriculum or outside influences caused these changes, the primary content of the classes where the shadowing intervention took place was academic writing, not listening comprehension, so the amount of listening practice in class was limited. English listening comprehension classes are only available as electives, meaning that only a small amount of students could have been influenced by these courses. Additionally, cross tabulation analysis shows that students' contact with English did not change significantly over the semester. Finally, the results from Ito's studies [11,20] combined with the increase in students' self-rated proficiency as found in the data analysis, indicate that students either maintained or improved their TOEIC scores on the listening section thanks to the shadowing system, when these scores normally decline. Students who shadowed more, reported higher linguistic self-confidence and perceived their listening abilities to be higher. It is possible that there is a connection between students' higher scores and higher linguistic self-confidence ratings.

Positive correlations with higher rates of shadowing practice and interest in communication in the L2 items suggest that shadowing may have an impact on students' interest in communicating with teachers, fellow students, other people from their country and foreigners. The overall means, however, for this construct, as analyzed through the $t$-tests, registered a decrease in the post-test results. It is possible that the language gain in speaking and listening through shadowing made communicating effectively in English seem more of a possibility than before for those who did more shadowing. 
Anxiety also seems to have been impacted positively, as indicated by a lower score on the item "I feel like other students in the class are better than me at English." The assertion that shadowing helps reduce anxiety is also supported by the negative correlation found between increased shadowing time and the items related to anxiety when the teacher speaks, as well as the items regarding feelings of uneasiness when people from their country speak to them. The lack of significant change or correlation for the other items might indicate that anxiety is only lowered when students are comparing themselves to others in their class. There is a possibility that the more a person shadowed, the more their anxiety decreased.

The more time a student spent on shadowing the more positive the view of their ideal L2 self became. Furthermore, $t$-tests showed higher means in the post-test for the item "I can imagine myself speaking English to other English speakers like a fluent speaker in 2 years" for the $t$-tests. The post-test means for the ideal L2 self construct were also higher.

Finally, overall student views of the efficacy of the shadowing intervention are favorable. Additionally, the more a person shadowed, the more they found shadowing effective in improving their English and an interesting way to study. Higher rates of shadowing also correlated with increased desire to use shadowing and increased motivation to study listening in the future. Students with higher shadowing rates were more likely to use shadowing for listening and speaking practice in other ways besides the shadowing system. Exploring further what motivates these students to use shadowing in their everyday lives through qualitative studies could provide further insight. Results of the descriptive statistics indicate that students may find shadowing boring, yet still see it as an effective tool for learning English and want to use it in the future to practice listening comprehension.

Clearly, not all of the students who took part in this study experienced the same language gains, enhanced motivation, or enjoyment. However, students who did shadow more saw benefits. It is likely that the focus on TOEIC played a role in some students' lower rates of shadowing. More autonomy in selection of materials could have interested students in the shadowing more, helping them shadow more than 15 min a week. As suggested by Kaneko [76], having role models could help students have a more solid image of their $\mathrm{f}$, thus influencing motivation. The shadowing of other varieties of English besides typical "white-middle class" Englishes often found in TOEIC texts, including Japanese varieties, may help students realize that their non-native variety of English is more than sufficient for communication.

Compared to Hamada's study of eight students who experienced shadowing in the classroom [79], students viewed shadowing more favorably overall, Results also indicate that it had a positive influence on motivation, mainly ideal L2 self, anxiety, linguistic self-confidence, and attitude towards speaking. This can be explained by the longer amount of time that learners had to become acquainted with shadowing plus the freedom they were given in choosing how to shadow. The MALL technology might also play a role in this difference. The use of technology might have made shadowing easier to practice because it allowed students the choice to study wherever and whenever they liked. Furthermore, as suggested by Noels [15], the autonomy granted by the application for students to monitor themselves and self-correct could have played a role.

\section{Limitations of the Study and Future Research Direction}

This study had several limitations. There was no control group and the respondents were not given ID numbers so only general tendencies could be explored because changes pertaining to each individual student could not be tracked over time. A TOEIC listening test was administered prior to and after shadowing to gauge changes in student achievement. However, since four different teachers were conducting the classes, the teachers' different approaches might have influenced how students approached their shadowing practice, taking the TOEIC test, and their attitudes. A mixed methods approach including interviews could help deepen the understanding of students' perceptions and how they specifically made use of the shadowing application. Nonetheless, this study did shed light on 
areas for further investigation and suggests that combining MALL technology and shadowing could be beneficial for students' motivation and English proficiency.

\section{Conclusions}

This study began with an overview of previous research in MALL, shadowing, and motivation in the field of second language acquisition, emphasizing a need for studies on how motivation can be enhanced by combining MALL and shadowing. It then turned to a description of a quantitative longitudinal study that investigated the effects of a shadowing application for mobile devices on learner motivation, perception of listening and speaking ability, and attitudes towards listening comprehension on 1001 students (mostly first-year science majors) at a university in Japan. During the 12-week intervention, students were given five shadowing tasks to complete outside of class weekly. Statistical analysis indicated that learner motivation and attitudes were higher for students that practiced shadowing more. Overall, the students saw either maintenance of or gains in English listening proficiency levels regardless of time spent shadowing, when under usual circumstances, proficiency test scores have a tendency decrease after the first year of university. Furthermore, students viewed shadowing as an effective method for studying English, with those who shadowed more showing greater interest in using shadowing in the future, and even doing listening comprehension more. This study provides findings that support the hypothesis that studying shadowing utilizing MALL technology could be beneficial to students' motivation and their actual and perceived English ability. In particular, students' linguistic self-confidence and ideal L2 self were improved significantly after the shadowing intervention. Anxiety levels decreased slightly and attitude towards English slightly improved, and the more a student used the shadowing application, the more positive their image of English became.

Further studies need to be conducted that investigate how students are influenced by activities introduced in the language classroom, not only in terms of proficiency, but also in terms of motivation and attitudes, as these aspects help to sustain the language learning process. This study contributes to these types of learning by providing insights into how a MALL application, constructed to address the challenges of students with limited exposure to English outside of the classroom, may enhance students' learning and motivation. Unlike previous studies, it provides a detailed analysis of the multifaceted nature of student motivation including instrumental motivation, linguistic self-confidence, anxiety, attitudes towards listening comprehension practice, interest in oral communication, and ideal L2 self. It also specifically focuses on oral communication rather than English as a whole. The majority of previous studies only focused on overall motivation, all four skills in English, and general interest in studying English.

The pedagogical implications are various, whether in terms of analyzing the effective use of shadowing or assessing whether or not to introduce MALL technology in the classroom in general. Additionally, giving students the liberty to do shadowing wherever and whenever makes the learning process less of a challenge. Providing a larger variety of materials to practice shadowing, or allowing students to choose their own materials to shadow may also make the practice of shadowing more interesting to students, amplifying the benefits of the practice. Finally, further studies that examine shadowing in comparison to other techniques for improving listening and speaking could shed more light on its efficacy.

Acknowledgments: I would like to express my sincere gratitude to David Beglar at Temple University and Tomoko Yashima at Kansai University for their feedback and encouragement. Most importantly, I would like to thank Kayo Ito at Kyoto University for sparking my interest in researching shadowing practice with MALL technology while also supporting me in my research.

Conflicts of Interest: The authors declare no conflict of interest. 


\section{Appendix A}

Table A1. Instrumental Motivation.

\begin{tabular}{|c|c|c|}
\hline Item Number & Item English & Item Japanese \\
\hline 1 & $\begin{array}{l}\text { I practice English listening comprehension } \\
\text { because I want to be able to communicate } \\
\text { well with other people }\end{array}$ & $\begin{array}{l}\text { 英語のリスンニング (聴解) を練習す } \\
\text { る理由は、他の人と英語で上手くコ } \\
\text { ミュニケーションでくるようになりた } \\
\text { いからだ }\end{array}$ \\
\hline 2 & $\begin{array}{l}\text { I practice English listening comprehension } \\
\text { because I want to study abroad }\end{array}$ & $\begin{array}{l}\text { 英語のリスンニング (聴解) を練習す } \\
\text { る理由は、留学したいからた }\end{array}$ \\
\hline 3 & $\begin{array}{l}\text { I practice English listening comprehension } \\
\text { because I want to work abroad }\end{array}$ & $\begin{array}{l}\text { 英語のリスンニング (聴解) を練習す } \\
\text { る理由は、海外で仕事をしたいからだ }\end{array}$ \\
\hline 4 & $\begin{array}{l}\text { I practice English comprehension because I } \\
\text { want to travel abroad }\end{array}$ & $\begin{array}{l}\text { 英語のリスンニング (聴解) を練習す } \\
\text { る理由は、海外旅行をしたいからだ }\end{array}$ \\
\hline 5 & $\begin{array}{l}\text { I practice English comprehension because I } \\
\text { may need it later for my future job }\end{array}$ & $\begin{array}{l}\text { 英語のリスンニング (聴解) を練習す } \\
\text { る理由は、将来の仕事に役に立つかも } \\
\text { しれないからだ }\end{array}$ \\
\hline 6 & $\begin{array}{l}\text { I practice English comprehension because I } \\
\text { may need it later for my future research }\end{array}$ & $\begin{array}{l}\text { 英語のリスンニング (恥解) を練習す } \\
\text { る理由は、将来の研究に役に立つかも } \\
\text { しれないからだ }\end{array}$ \\
\hline
\end{tabular}

Table A2. Linguistic Self-Confidence.

\begin{tabular}{cll}
\hline Item Number & \multicolumn{1}{c}{ Item English } & \multicolumn{1}{c}{ Item Japanese } \\
\hline 7 & English listening comprehension is easy & 英語リスニング (聴解) は簡単だ \\
8 & English listening comprehension is difficult & 英語リスニング (聴解) は難しい \\
9 & I am good at learning English & 英語学習が得意だ \\
20 & I know effective ways to study English & 英語リスニング (恥解) の効果的 \\
& listening comprehension & な学習法を知っている \\
\hline
\end{tabular}

Table A3. Anxiety.

\begin{tabular}{|c|c|c|}
\hline Item Number & Item English & Item Japanese \\
\hline 10 & $\begin{array}{l}\text { I feel like other students in my class are better } \\
\text { than me at English }\end{array}$ & $\begin{array}{l}\text { 私のクラスの他の生徒の方が、私 } \\
\text { より英語が上手だと感し }\end{array}$ \\
\hline 12 & $\begin{array}{l}\text { I get uneasy when my teacher speaks to the } \\
\text { class in English }\end{array}$ & $\begin{array}{l}\text { 先生がクラス全員に英語を話す } \\
\text { と、不安になる }\end{array}$ \\
\hline 14 & $\begin{array}{l}\text { I feel uneasy when my teacher speaks to me } \\
\text { in English }\end{array}$ & $\begin{array}{l}\text { 先生から英語を話されると、不安 } \\
\text { になる }\end{array}$ \\
\hline 16 & $\begin{array}{l}\text { I feel uneasy when English is spoken to me by } \\
\text { other people from my country }\end{array}$ & $\begin{array}{l}\text { 同じ国の人から英語を話される } \\
\text { と、安になる }\end{array}$ \\
\hline
\end{tabular}

Table A4. Interest in the L2.

\begin{tabular}{|c|c|c|}
\hline Item Number & Item English & Item Japanese \\
\hline 11 & $\begin{array}{l}\text { I get excited when my teacher speaks to the class } \\
\text { in English }\end{array}$ & $\begin{array}{l}\text { 先生がクラス全員に英語を話すと、わく } \\
\text { わくる }\end{array}$ \\
\hline 13 & $\begin{array}{l}\text { I get excited when my teacher speaks to me in } \\
\text { English }\end{array}$ & $\begin{array}{l}\text { 先生から英語を話されると、わくわくす } \\
\text { る }\end{array}$ \\
\hline 15 & $\begin{array}{l}\text { I get excited when English is spoken to me by } \\
\text { other people from my country }\end{array}$ & $\begin{array}{l}\text { 同じ国の人から英語を話されると、わく } \\
\text { わする }\end{array}$ \\
\hline 17 & $\begin{array}{l}\text { I get excited when English is spoken to me by } \\
\text { foreigners }\end{array}$ & $\begin{array}{l}\text { 外国人から英語を話されると、わくわく } \\
\text { する }\end{array}$ \\
\hline 31 & $\begin{array}{l}\text { I really want to be able to understand spoken } \\
\text { English }\end{array}$ & $\begin{array}{l}\text { 話されている英語を理解できるようにな } \\
\text { クたい }\end{array}$ \\
\hline 32 & $\begin{array}{l}\text { Being able to understand spoken English is } \\
\text { important to me }\end{array}$ & $\begin{array}{l}\text { 私にとって話されている英語を理解でき } \\
\text { ることは大事だ }\end{array}$ \\
\hline
\end{tabular}


Table A5. Intended Study Effort.

\begin{tabular}{ccc}
\hline Item Number & Item English & \multicolumn{1}{c}{ Item Japanese } \\
\hline 19 & $\begin{array}{c}\text { I am working hard on improving my English } \\
\text { listening comprehension }\end{array}$ & $\begin{array}{l}\text { 英語リスニング (聴解) } \\
\text { 命勉強している 生懸 }\end{array}$ \\
\hline
\end{tabular}

Table A6. Ideal L2 Self.

\begin{tabular}{|c|c|c|}
\hline Item Number & Item English & Item Japanese \\
\hline 21 & $\begin{array}{l}\text { I believe I will be able to understand } \\
\text { spoken English with little difficulty if I } \\
\text { keep practicing listening } \\
\text { comprehension }\end{array}$ & $\begin{array}{l}\text { もしリスニング (恥解) を学習し続け } \\
\text { たら、口語英語をほとんど支障なく理 } \\
\text { 解することができるようになると思う }\end{array}$ \\
\hline 22 & $\begin{array}{l}\text { I can imagine myself listening to news } \\
\text { in English with little difficulty } 2 \text { years } \\
\text { from now }\end{array}$ & $\begin{array}{l}2 \text { 年後に英語のニュースをほとんど支 } \\
\text { 障なく聞き取れている自分を思い描く } \\
\text { ことができる }\end{array}$ \\
\hline 23 & $\begin{array}{l}\text { I can imagine myself listening to news } \\
\text { in English with little difficulty } 4 \text { years } \\
\text { from now }\end{array}$ & $\begin{array}{l}4 \text { 年後に英語のニュースをほとんど支 } \\
\text { 障なく聞き取れている自分を思い描く } \\
\text { ことができる }\end{array}$ \\
\hline 24 & $\begin{array}{l}\text { I can image myself speaking English to } \\
\text { other English speakers like a fluent } \\
\text { speaker in } 2 \text { years }\end{array}$ & $\begin{array}{l}2 \text { 年以内に英語話者と流暢に英語を話 } \\
\text { す自分を思い描くことができる }\end{array}$ \\
\hline 25 & $\begin{array}{l}\text { I can image myself speaking English to } \\
\text { other English speakers like a fluent } \\
\text { speaker in } 4 \text { years }\end{array}$ & $\begin{array}{l}4 \text { 年以内に英語話者と流暢に英語を話 } \\
\text { す自分を思い描くことができる }\end{array}$ \\
\hline 26 & $\begin{array}{l}\text { I often imagine myself speaking and } \\
\text { listening to English with little difficulty }\end{array}$ & $\begin{array}{l}\text { 自分がほとんど支障なく英語を話した } \\
\text { り聞いたりしていることをしばしば想 } \\
\text { 像する }\end{array}$ \\
\hline 27 & $\begin{array}{l}\text { I can imagine myself using English in a } \\
\text { variety of ways in } 2 \text { years }\end{array}$ & $\begin{array}{l}2 \text { 年以内に様々な方法で英語を利用し } \\
\text { ている自分を思い描くことができる }\end{array}$ \\
\hline 28 & $\begin{array}{l}\text { I can imagine myself using English in a } \\
\text { variety of ways in } 4 \text { years }\end{array}$ & $\begin{array}{l}4 \text { 年以内に様々な方法で英語を利用し } \\
\text { ている自分を思い描くことができる }\end{array}$ \\
\hline 29 & $\begin{array}{l}\text { I can imagine myself being able to } \\
\text { understand almost all spoken English in } \\
\text { the future }\end{array}$ & $\begin{array}{l}\text { 将来、ほとんどすべての口語英語を理 } \\
\text { 解することができるようになると思う }\end{array}$ \\
\hline
\end{tabular}

Table A7. Attitudes towards Listening Comprehension Practice in the L2.

\begin{tabular}{cll}
\hline Item Number & \multicolumn{1}{c}{ Item English } & \multicolumn{1}{c}{ Item Japanese } \\
\hline \multirow{2}{*}{30} & $\begin{array}{l}\text { I really like doing listening comprehension } \\
\text { practice }\end{array}$ & $\begin{array}{l}\text { 英語リスニング(恥解)の練習をす } \\
\text { るのはとても好きだ }\end{array}$ \\
\hline
\end{tabular}

Table A8. English Contact.

\begin{tabular}{|c|c|c|}
\hline Item Number & Item English & Item Japanese \\
\hline 33 & $\begin{array}{l}\text { How often do you meet speakers of English } \\
\text { (including non-native speakers) in a week? }\end{array}$ & $\begin{array}{l}\text { 一週間にどの程度、英語話者（非 } \\
\text { 母語話者を含む）に会いますか }\end{array}$ \\
\hline 34 & $\begin{array}{l}\text { How often do you hear English spoken in the } \\
\text { media (TV, Movies, et cetera) in a week? }\end{array}$ & $\begin{array}{l}\text { メディア (テレビ、英語、など }) \\
\text { で、一週間にどの程度、英語を聞 } \\
\text { きますか }\end{array}$ \\
\hline 35 & How often do you listen to English music? & $\begin{array}{l}\text { 一週間にどの程度、英語の音楽を } \\
\text { 聞きますか }\end{array}$ \\
\hline
\end{tabular}


Table A9. Additional Post-Test Questions: Students' Perceptions of the Utility of Shadowing.

\begin{tabular}{|c|c|c|}
\hline Item Number & Item English & Item Japanese \\
\hline 36 & Shadowing is interesting & シャドーイングは面白い \\
\hline 37 & Shadowing is boring & シャドーイングはつまらない \\
\hline 38 & $\begin{array}{l}\text { My listening comprehension skills improved } \\
\text { thanks to shadowing }\end{array}$ & $\begin{array}{l}\text { シャドーイングの練習のおかげ、 } \\
\text { リスニングがよくなった }\end{array}$ \\
\hline 39 & $\begin{array}{l}\text { Shadowing is an effective technique for } \\
\text { studying English }\end{array}$ & $\begin{array}{l}\text { シャドーイングは英語学習に効果 } \\
\text { がある }\end{array}$ \\
\hline 40 & $\begin{array}{l}\text { Thanks to shadowing, I want to do more } \\
\text { listening comprehension practice }\end{array}$ & $\begin{array}{l}\text { シャドーイングのおかげで聞き取 } \\
\text { ク練習をもっとしたくなった }\end{array}$ \\
\hline 41 & $\begin{array}{l}\text { I find myself doing shadowing in my every } \\
\text { day life }\end{array}$ & $\begin{array}{l}\text { 日常生活においてもシャドーイン } \\
\text { グをしていることがある }\end{array}$ \\
\hline 42 & $\begin{array}{l}\text { In the future, I want to use shadowing to } \\
\text { practice English listening comprehension }\end{array}$ & $\begin{array}{l}\text { 今後、リスニングの練習の為に } \\
\text { シャドーイングを使っていきたい }\end{array}$ \\
\hline
\end{tabular}

\section{How much did you practice shadowing this semester?}

今学期、一週間にどの程度、シャドーイングをしましたか？

Less than 15 min a week週十五分未満

15 to 30 min a week 週十五分加三十分間

$30 \mathrm{~min}$ to an hour a week 週三十分から一時間

1 to $2 \mathrm{~h}$ a week週一時間加二時間

More than $2 \mathrm{~h}$ a week週二時間以上

\section{English ability question:}

English ability: Please rate your current listening ability in English by ticking one.

1 Upper Intermediate level and over-Able to understand conversations general matters of daily life and topics of one's specialty and grasp the gist of lectures and broadcasts.

2 Intermediate level-Able to understand conversations about general matters of daily life.

3 Lower Intermediate level-Able to understand conversations about familiar daily topics.

4 Post-Beginner level-Able to understand a simple conversation such as greeting and introducing someone.

5 Beginner level—Able to understand simple greetings using set words and phrases.

英語力：あなたの現在のリスニングに関する英語力について次の中から一つに印をつけて ください。

1 中上級レベル以上一日常生活の一般的な事柄や専門的な事柄についての会話の聞き取りができ、 講義や放送の大意を理解できる。

2 中級レベル一日常生活の一般的な事柄に関する会話の聞き取りができる。

3 初中級レベル一日常生活の身近な事柄についての会話の聞き取りができる。

4 初級レベル一挨拸や人の紹介などの簡単な会話の聞き取りができる。

5 基礎しベル一決まり文句を用いて簡単な挨拸の聞き取りができる。

42 Have you spent more than three months in an English-speaking country in the past 10 years? 過去十年間、少なくとも計 3 ケ月以上英語圈に滞在したことがありますか?

Yes No

はいいいえ 
43 Have you spent more than three months in an English-speaking country in your life?

少なくとも計３ ケ月以上英語圏に帯在したことがありますか？

Yes No

はいいいえ

44 Have you ever been to an English-speaking country in your life?

今まで英語圏に滞在したことがありますか?

Yes No

はいいいえ

45 Gender 性別

Male 男 Female 女

46 Nationality 国籍

Japanese 日本人

Non-Japanese 外国人

\section{Major}

Humanities 総合人間学部

Literature 文学部

Education 教育学部

Law 法学部

Economics経済学部

Medicine 医学部

Engineering工学部

Agriculture 農学部

\section{References}

1. Maeda, M. Uniqlo, Rakuten make official language English. Japan Center for Economic Research, 15 July 2010. Available online: www.jcer.or.jp/eng/research/pdf/maeda20100715e.pdf (accessed on 15 January 2017).

2. Teeter, J. Exploring the potential of TBLT for academic abstract writing. OnTask J. JALT Task Based Learn. SIG 2014, 4, 9-20.

3. Kubota, R. The impact of globalization on language teaching in Japan. In Globalization and Language Teaching; Block, D., Cameron, D., Eds.; Routledge: London, UK, 2002; pp. 13-28.

4. Monbukagakushō (Ministry of Education, C., Sports, Science and Technology (MEXT), Shōgakkō no Aratana Gaikokugokyōiku ni Okeru Hojo Kyōzai (Hi, Friends! Story Books) Sakusei ni Tsuite (dai 34 Gakunen-yō)' (On the Creation of Supplementary Textbooks for the New Foreign Language Curriculum in Elementary Schools (Hi, Friends! Story Books) (for 3rd and 4th Grade). 2016. Available online: http:/ /www.mext.go.jp/ a_menu/kokusai/gaikokugo/1370103.htm (accessed on 20 February 2017).

5. Monbukagakushō (Ministry of Education, Culture, Sports, Science and Technology (MEXT), Heisei 27-Nendo "Eigo Kyōiku Jisshi Jōkyō Chōsa' no Kekka ni Tsuite" [On the Results of "Survey on the Implementation Status of English Education" in FY2015]. 2016. Available online: http:/ /www.mext.go.jp/a_menu/kokusai/ gaikokugo/1369258.htm (accessed on 22 February 2017).

6. Okazaki, T. Eigo kyōiku to senjūmin-zoku gengo fukkō Maori-go, ainu-go o chūshin ni [Education in English and Indigenous Language Revitalization-focusing on Maori and Ainu Languages]. In Gengo to Kyōiku-Kattō Kara Daisan no Michi e (Language and Education-From Conflict to Third Way); Sugino, T., Tanaka, F., Hatano, K., Eds.; Meiji Shoten: Tokyo, Japan, 2017; in press. 
7. Hulstijn, J.H. Intentional and incidental second language vocabulary learning: A reappraisal of elaboration, rehearsal and automaticity. In Cognition and Second Language Instruction; Robinson, P., Ed.; Cambridge University Press: Cambridge, UK, 2001; pp. 258-286.

8. Sumida, A.; Kobayashi, W.; Gutierrez, T. Eigo shūjuku-do tesuto ni mi rareru daigaku 1-nensei no eigodjikara no suii [Tendencies in English proficiency of university first year students as seen through analysis of English proficiency test results]. Nihon Univ. Inst. Hum. Soc. Sci. Bull. 2015, 90, 131-144. Available online: http:/ / www.chs.nihon-u.ac.jp/institute/human/kiyou/90/8.pdf (accesed on 10 June 2017).

9. Mikada, H. Kōgakubu kōgaku kenkyū-ka ni okeru IR kekka to akushon IIR Results and Actions at the Faculty of Engineering]. In Dai 20-kai Kyōtodaigaku Zengaku Kyōiku Shinpojiumu Hōkoku-Sho: Dēta to Risō ni Motodzuite Kangaeru Kyōdai no Kyōiku Kaikaku:Nyūshi Kara Daigakuin Kyōiku Made [The 20th Kyoto University General Education Symposium Report: On Educational Reform Based on Data and Ideals-From Admissions to Graduate School Education]; Kyoto University Faculty Development Committee: Kyoto, Japan, 2016; Available online: http:/ / www.fd.kyoto-u.ac.jp/activity/shimposium2016.pdf (accessed on 15 June 2017).

10. Kanamaru, T. Study a new kind of English offered by Kyoto University. Arts Sci. Newslett. 2014, 19, 5. Available online: http:/ / www.z.k.kyoto-u.ac.jp/pdf/link/link0339.pdf?1417539122 (accesed on 10 June 2017).

11. Ito, K.; Teeter, J.; Murakami, A.; Nakano, M. Strengthening English listening skills: The development of a self-study shadowing system for tablets and smart phones. In Proceedings of the 6th Joint Foreign Language Education and Technology Conference, Cambridge, MA, USA, 12-15 August 2015.

12. Gardner, R.C. Social Psychology and Second Language Learning; Edward Arnold: London, UK, 1985.

13. Ellis, R. Second Language Acquisition; Oxford University Press: Oxford, UK, 1997.

14. Ajzen, I. Attitude, Personality and Behavior, 2nd ed.; Open University Press: New York, NY, USA, 2005.

15. Noels, K.A. Learning Japanese; Learning English: Promoting Motivation Through Autonomy, Competence and Relatedness. In Language Learning Motivation in Japan; Apple, M.T., Da Silva, D., Fellner, T., Eds.; Multilingual Matters: Bristol, UK, 2013; pp. 15-34.

16. Bernaus, M.; Gardner, R.C. Teacher motivation strategies, student perceptions, student motivation, and English achievement. Mod. Lang. J. 2008, 92, 378-401. [CrossRef]

17. Dörnyei, Z. The L2 Motivational Self System. In Motivation, Language Identity and the L2 Self; Dörnyei, Z., Ushioda, E., Eds.; Multilingual Matters: Bristol, UK, 2009; pp. 9-42.

18. Harmon, D., II. Teaching Fluency and Rhythm to Learners Using Reading Aloud and Shadowing Dennis Harmon II. In Teaching the SoundsSystem of English; Barbieri, N., Giordano, M., Eds.; Temple University, Japan Campus: Tokyo, Japan, 2014; pp. 33-43.

19. Rico, M.; Naranjo, M.J.; Delicado, G.; Plaza, N.; Domínguez, E. Let's move: Mobile learning for motivation in language acquisition. In Proceedings of the 7th ICT for Language Learning, Florence, Italy, 13-14 November 2014; pp. 91-94.

20. Ito, K.; Nakano, M. In Risuningu kyōka no tame ni shadōingu o daburetto ya sumaho de jishu gakushū dekiru shisutemu kōchiku [Strengthening English listening skills: The development of a self-study shadowing system for tablets and smart phones]. In Proceedings of the 55th Annual Conference of The Japan Association for Language Education and Technology, Kansai University, Osaka, Japan, 4-6 August 2015; pp. 74-75.

21. Ryan, S. Self and identity in L2 motivation in Japan: The ideal L2 self and Japanese learners of English. In Motivation, Language Identity and the L2 Self; Dörnyei, Z., Ushioda, E., Eds.; Multilingual Matters: Bristol, UK, 2009; pp. 120-143.

22. Pigott, J. Motivation and complex systems theory: An exploratory view of the motivation of four Japanese university students. OnCue 2013, 6, 27-47. Available online: http:/ / www.jaltcue.org/files/OnCUE/OCJ6.2/ OCJ6.2_pp27-47_Pigott.pdf (accessed on 14 June 2017).

23. Sharples, M.; Milrad, M.; Arnedillo Sánchez, I.; Vavoula, G. Mobile Learning: Small Devices, Big Issues. In Technology-Enhanced Learning: Principles and Products; Balacheff, N., Ludvigsen, S., Eds.; Springer: Berlin, Germany, 2009; pp. 233-249.

24. Valarmathi, K.E. Mobile assisted language learning. J. Technol. ELT 2011, 2, 1-8. Available online: https:/ / sites.google.com/site/journaloftechnologyforelt/archive/april2011/mobileassistedlanguagelearning (accessed on 14 June 2017).

25. Poushter, J. Smartphone ownership and Internet usage continues to climb in emerging economies. Pew Res. Center Glob. Attitudes Trends 2016, 22. Available online: www.pewglobal.org/2016/02/22/smartphoneownership-and-internet-usage-continues-to-climb-in-emerging-economies / (accessed on 14 June 2017). 
26. Senao, A. Chōsa dēta: Kōkōsei no sumātofon shoyū-ritsu wa 93. 0\%, 2014nen yori 13. 5-pointo appu [Survey data: The ownership rate of smartphones by high school students is 93.0\%, 13.5 points higher than 2014]. Mobile Marketing Laboratory. 20 September 2016. Available online: https:/ / mmdlabo.jp/investigation/detail_ 1605.html (accessed on 12 June 2017).

27. Prensky, M. Digital natives, digital immigrants. Horizon 2001, 9, 1-6. Available online: http:/ / www.marcprensky.com/writing/Prensky\%20\%20Digital\%20Natives, \%20Digital\%20Immigrants\% 20-\%20Part1.pdf (accessed on 12 June 2017).

28. Pedró, F. Trusting the unknown: The effects of technology use in education. In The Global Information Technology Report; The World Economic Forum: Geneva, Switzerland, 2012; pp. 135-146.

29. Wu, W.-H.; Wu, Y.-C.J.; Chen, C.-Y.; Kao, H.-Y.; Lin, C.-H.; Huang, S.-H. Review of trends from mobile learning studies: A meta-analysis. Comput. Educ. 2012, 59, 817-827. [CrossRef]

30. Al-Jarf, R. Mobile technology and student autonomy in oral skill acquisition. In Left to My Own Devices: Learner Autonomy and MALL Innovation and LEADERSHIP in English Language Teaching; Díaz-Vera, J., Ed.; Emerald Group: Bingley, UK, 2012; pp. 105-130.

31. Liu, T.-Y.; Chu, Y. Using ubiquitous games in an English listening and speaking course: Impact on learning outcomes and motivation. Comput. Educ. 2010, 55, 630-643. [CrossRef]

32. Sato, T.; Murase, F.; Burden, T. Is mobile-assisted language learning really useful? An examination of recall automatization and learner autonomy. In Proceedings of the EUROCALL Conference, Padova, Italy, 26-29 August 2015; Helm, F., Bradley, L., Guarda, M., Thouësny, S., Eds.; Research-Publishing.net: Padova, Italy, 2015; pp. 495-501.

33. Thornton, P.; Houser, C. Using mobile phones in English education in Japan. J. Comput. Assist. Learn. 2005, 21, 217-228. [CrossRef]

34. Bovee, N.; Stewart, J. The utility of shadowing. In Proceedings of the JALT2008 Conference Proceedings, Tokyo, Japan, 31 October-3 November 2009, pp. 888-900. Available online: http:/ /jalt-publications.org/ recentpdf/proceedings/2008/E158.pdf (accessed on 15 February 2017).

35. Harbison, D.C., Jr.; Porter, R.J., Jr.; Tobey, E.A. Shadowed and simple reaction times in stutterers and nonstutterers. J. Acoust. Soc. Am. 1989, 86, 1277-1284. [CrossRef] [PubMed]

36. Shlesinger, M.; Pochhacker, P. Aptitude for Interpreting; John Benjamins Publishing Company: Amsterdam, The Netherlands, 2011.

37. Murphey, T. Exploring conversational shadowing. Lang. Teach. Res. 2001, 5, 128-155. [CrossRef]

38. Hamada, Y. The effectiveness of pre- and post-shadowing in improving listening comprehension skills. Lang. Teach. 2014, 38, 3-10.

39. Foote, J.A.; McDonough, K. Using shadowing with mobile technology to improve L2 pronunciation. J. Second Lang. Pronunciation 2017, 3, 34-56. [CrossRef]

40. Rongna, A.; Hayahi, R. Accuracy of Japanese pitch accent rises during and after shadowing training. In Proceedings of the 6th International Conference on Speech Prosody, Shanghai, China, 22-25 May 2012; Tongji University Press: Shanghai, China, 2012; pp. 143-146.

41. Yamane, S.; Saito, E.; Yashima, T. Ripītingu ga eigo purosodī no shūtoku ni ataeru kōka [The effects of repeating on acquiring prosody]. Kotobano Kagaku Kenkyuu 2004, 5, 45-51.

42. Torikai, M.; Tamai, K.; Someya, T.; Tanaka, M.; Tsuruda, C.; Nishimura, T. Hajimete no shadoingu [Shadowing for the first time]; Gakken Marketing: Tokyo, Japan, 2003.

43. Mochizuki, H. Application of shadowing to TEFL in Japan: The case of junior high school students. Stud. Engl. Lang. Teach. KELES 2006, 29, 29-44. Available online: http://www.keles.jp/activity/selt/backnumber/ 2006_no29/ (accessed on 10 February 2017).

44. Nakayama, T.; Suzuki, A. Gakushū hōryaku no chigai ga shadowingu no fukushōryō ni ataeru eikyō [A study on learning strategies in shadowing training]. Rimediaru kyōiku kenkyū [J. Jpn. Assoc. Dev. Educ.] 2012, 7, 131-140. Available online: https://www.jstage.jst.go.jp/article/jade/7/1/7_KJ00008635818/_pdf (accessed on 15 February 2017).

45. Mori, Y. Shadowing with Oral Reading: Effects of Combined Training on the Improvement of Japanese EFL Learners' Prosody. Lang. Educ. Technol. 2011, 48, 1-22. Available online: http://ci.nii.ac.jp/naid/ 110008686398 (accessed on 15 February 2017).

46. Hamada, Y. Shadowing: Who benefits and how? Uncovering a booming EFL teaching technique for listening comprehension. Lang. Teach. Res. 2016, 20, 35-52. [CrossRef] 
47. Tamai, K. "Follow-up" no chōkairyoku ni oyoba su kōka oyobi "follow-up" nōryoku to chōkairyoku no kankei [The effects of followup tasks on listening comprehension and the relationship between follow-up ability and listening comprehension]. STEP Bull. 1992, 48-62. Available online: https://www.eiken.or.jp/ center_for_research/pdf/bulletin_archives/vol_04.pdf (accessed on 10 June 2017).

48. Tamai, K. Risuningu Shidō-Hō to Shite no Shadōin gu no Kōka ni Kansuru Kenkyū [Research on the Effects of Using Shadowing as a Method of Teaching Listening]; Kazama Shobo: Tokyo, Japan, 2005.

49. Kato, S. Kōkū eigo nōryoku shōmei shūtoku o mezashita risuningu shidō no kōsatsu [Listening activities for the acquisition of Aviation English proficiency test]. Bull. Chiba Univ. Lang. Cult. 2009, 47-59. Available online: http:/ / mitizane.ll.chiba-u.jp/meta-bin/mt-pdetail.cgi?cd=00066721 (accessed on 10 June 2017).

50. Kadota, S. Shadoingu to Ondoku no Kagaku [The Science of Shadowing and Oral Reading]; Cosmopier: Tokyo, Japan, 2007.

51. Nakayama, T.; Armstrong, T. Weak forms in shadowing: How can Japanese EFL learnersperform better on shadowing tasks? Jissen Women's Univ. CLEIP J. 2015, 13-21. Available online: https:/ /jissen.repo.nii.ac.jp/ ?action=repository_uri\&item_id=1323\&file_id=22\&file_no=2 (accessed on 10 June 2017).

52. Lightbown, P.M.; Spada, N.M. How Languages Are Learned; Oxford University Press: Oxford, UK, 2013.

53. Masgoret, A.-M.; Gardner, R.C. Attitudes, Motivation, and Second Language Learning: A Meta-Analysis of Studies Conducted by Gardner and Associates. Lang. Learn. 2003, 53, 167-210. [CrossRef]

54. Noels, K.A.; Pelletier, L.G.; Vallerand, R.J. Why are you learning a second language? Motivational orietation and self-determination theory. Lang. Learn. 2000, 50, 57-85. [CrossRef]

55. Gardner, R.C.; Lambert, W.E. Motivational variables in second language acquisition. Can. J. Psychol. 1959, 13, 191-197. [CrossRef]

56. Dornyei, Z. Teaching and Researching Motivation; Longman: Harlow, UK, 2001.

57. Gardner, R.C. Integrative motivation and second language learning. In Motivation and Second Language Acquisition; Dornyei, Z., Schmidt, R., Eds.; University of Hawaii Press: Honolulu, HI, USA, 2001; pp. 1-20.

58. Crookes, G.; Schmidt, R. Motivation: Reopening the research agenda. Lang. Learn. 1991, 41, 469-512. [CrossRef]

59. Noels, K. New orientations in language learning motivation: Toward a model of intrinsic, extrinsic, and integrative orientations and motivations. In Motivation and Second Language Acquisition; University of Hawaii: Honolulu, HI, USA, 2001; pp. 43-68.

60. Peirce, B.N. Social Identity, Investment, and Language Learning. TESOL Q. 1995, 29, 9-31. [CrossRef]

61. Irie, K.; Brewster, D. One Curriculum, three Stories: Ideal L2 self and L2-Self-Discrepancy profiles. In Language Learning Motivation in Japan; Apple, M., Silva, D.D., Fellner, T., Eds.; Multilingual Matters: Bristol, UK, 2013; pp. 110-128.

62. Munezane, Y. Motivation, Ideal L2 Self, and valuing of Global English. In Language Learning Motivation in Japan; Apple, M., Silva, D.D., Fellner, T., Eds.; Multilingual matters: Bristol, UK, 2013; pp. 152-168.

63. Matsuoka, R.; Rahimi, A. The positive effect of conference participation on reducing L2 communication apprehension. Procedia Soc. Behav. Sci. 2010, 9, 1845-1854. [CrossRef]

64. Ehrman, M.E. An exploration of adult language learners' motivation, self-efficacy, and anxiety. In Language Learning Motivation: Pathways to the New Century; Oxford, R.L., Ed.; University of Hawaii: Honolulu, HI, USA, 1996; pp. 81-103.

65. Noels, K.A.; Pon, G.; Clement, R. Language, Identity, and Adjustment. J. Lang. Soc. Psychol. 1996, 15, $246-264$. [CrossRef]

66. Tremblay, P.F.; Gardner, R.C. Expanding the Motivation Construct in Language Learning. Mod. Lang. J. 1995, 79, 505-518. [CrossRef]

67. Julkunen, K. Situation and Task Specific Motivation in Foreign-Language Learning and Teaching; University of Joensuu: Joensuu, Finland, 1989.

68. Andrade, M.; Williams, K. Foreign language learning anxiety in Japanese EFL university classes: Physical, emotional, expressive, and verbal reactions. Sophia Jr. Coll. Fac. J. 2009, 29, 1-24. Available online: https:/ / www.jrc.sophia.ac.jp/pdf/research/bulletin/ver2901.pdf (accessed on 10 February 2017).

69. Yashima, T.; Noels, K.; Shizuka, T.; Takeuchi, O.; Yamane, S.; Yoshizawa, K. The interplay of classroom anxiety, intrinsic motivation, and gender in the Japanese EFL context. Kansai Univ. J. Foreign Lang. Educ. Res. $2008,17,41-64$. 
70. Yashima, T. Willingness to Communicate in a Second Language: The Japanese EFL Context. Mod. Lang. J. 2002, 86, 54-66. [CrossRef]

71. Dörnyei, Z. The Psychology of the Language Learner: Individual Differences in Second Language Acquisition; Lawrence Erlbaum: Mahwah, NJ, USA, 2005.

72. Johnson, M.P. A longitudinal perspective on EFL learning motivation in Japanese engineering students. In Language Learning Motivation in Japan; Apple, M., Fellner, D.D.S.T., Eds.; Multilingual Matters: Bristol, UK, 2013; pp. 189-205.

73. Kimura, Y.; Nakata, Y.; Okumura, T. Language Learning Motivation of EFL Learners in Japan-A Cross-Sectional Analysis of Various Learning Milieus. JALT J. 2001, 23, 47-68. Available online: http:/ /jalt-publications.org/archive/jj/2001a/art3.pdf (accessed on 13 June 2017).

74. Falout, J.; Maruyama, M. A Comparative Study of Proficiency and Learner Demotivation. Lang. Teach. 2004, 28, 3-9. Available online: http:/ /jalt-publications.org/files/pdf-article/tlt38.1-art1.pdf (accessed on 10 June 2017).

75. Apple, M.T.; Falout, J.; Hill, G. Exploring classroom-based constructs of EFL motivation for science and engineering students in Japan. In Language Learner Motivation in Japan; Apple, M.T., Da Silva, D., Fellner, T., Eds.; Multilingual Matters: Bristol, UK, 2013; pp. 54-74.

76. Kaneko, E. On the motivation of science majors learning English a foreign language: A case study from Japan. OnCUE 2012, 6, 3-26. Available online: jaltcue.org/files/OnCUE/OCJ6.2/OCJ6.2_pp3-26_Kaneko.pdf (accessed on 10 June 2017).

77. Chen, Y.; Liska, C.; Smith, T.J. Mobile-assisted narrative writing practice for young English language learners from a funds of knowledge approach. Lang. Learn. Technol. 2017, 21, 28-41. Available online: http:/ /llt.msu.edu/issues / february2017/chencargersmith.pdf (accessed on 10 June 2017).

78. Colibaba, A.; Ursa, O.; Arhip, C.; Gheorgiu, I.; Colibaba, S. Take Care of Mobile Learning! In Proceedings of the 7th ICT for Language Learning, Florence, Italy, 13-14 November 2014; pp. 319-322.

79. Hamada, Y. Uncovering shadowing as an EFL teaching technique for listening: Learners' perceptions, self-confidence, and motivation. Akita Daigaku Kyōyō Kiso Kyōiku Kenkyū Nenpō [Akita University Annual Report on General Education Research]. 2015; pp. 9-22. Available online: http:/ / air.lib.akita-u.ac.jp/dspace/ bitstream/10295/2779/1/kkiso17(9).pdf (accessed on 10 February 2017).

80. Li-Chi, L. A Study of Using Shadowing As a Task in Junior High School EFL Program in Taiwan; National Taiwan University of Science and Technology: Taipei, Taiwan, 2009.

81. Saishin kyōto fu daigaku hensa chi ichiran 2017 (Latest Kyoto Prefecture academic deviation rankings list). Daigaku Juken Boy. 2017. Available online: http:/ / daigakujyuken.boy.jp/indexkyoutofu.html/ (accessed on 10 September 2017).

82. Aotani, M. Eigo Gakushū. TOEFL Setsumei Kai (hi Eiri. Kōkai. Muryō)—SUPĪKINGU to Sōgō Ryoku (Studying English. TOEFL Briefing Session (Non-Profit, Open to the Public, Free)-Speaking and Overall Ability) Aotani Homepage 2013. Available online: http://aoitani.net/TOEFL_12.html (accessed on 10 June 2017).

83. Obunsha, Eiken 1-kyū yosōmondai doriru shin shiken taiō-ban (onsei DL-tsuki) [Eiken Level 1 Practice Drills for the new version (with recording)]. Obunsha: Tokyo, Japan, 2015.

84. Taguchi, T.; Magid, M.; Papi, M. Appendix B. In Questionnaires in Second Language Research: Construction, Administration, and Processing; Dörnyei, Z., Ushioda, E., Eds.; Taylor \& Francis: New York, NY, USA; London, UK, 2010.

85. Suzuki, W.; Leis, A.; Ando, A.; Itagaki, N. Nihonjin Daigakusei no Eigo Gakushū ni Taisuru Dōkidzuke Chōsa-Dörnyei no L 2 Motivational Self System Nimotozuite-Miyagi Educational University Research Center for Education in International Understanding Annual Report. 2011; pp. 15-33. Available online: http:/ / rceiu.miyakyo-u.ac.jp/imgnenpou2010/ron3\%20saai.pdf (accessed on 10 June 2017).

(C) 2017 by the author. Licensee MDPI, Basel, Switzerland. This article is an open access article distributed under the terms and conditions of the Creative Commons Attribution (CC BY) license (http://creativecommons.org/licenses/by/4.0/). 